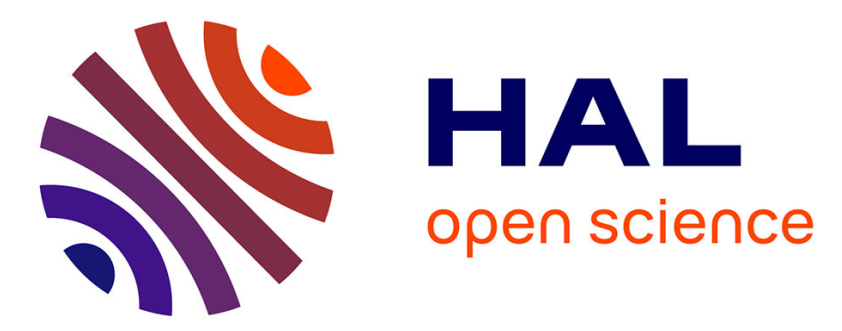

\title{
Effects of stand composition and tree size on resistance and resilience to drought in sessile oak and Scots pine
}

M. Merlin, Thomas Perot, Sandrine Perret, Nathalie Korboulewsky, P. Vallet

\section{To cite this version:}

M. Merlin, Thomas Perot, Sandrine Perret, Nathalie Korboulewsky, P. Vallet. Effects of stand composition and tree size on resistance and resilience to drought in sessile oak and Scots pine. Forest Ecology and Management, 2015, 339, pp.22-33. 10.1016/j.foreco.2014.11.032 . hal-01140201

\section{HAL Id: hal-01140201 https://hal.science/hal-01140201}

Submitted on 8 Apr 2015

HAL is a multi-disciplinary open access archive for the deposit and dissemination of scientific research documents, whether they are published or not. The documents may come from teaching and research institutions in France or abroad, or from public or private research centers.
L'archive ouverte pluridisciplinaire HAL, est destinée au dépôt et à la diffusion de documents scientifiques de niveau recherche, publiés ou non, émanant des établissements d'enseignement et de recherche français ou étrangers, des laboratoires publics ou privés. 
1 Effects of stand composition and tree size on resistance and resilience to drought in sessile

2 oak and Scots pine

3

4 Morgane Merlin, Thomas Perot, Sandrine Perret, Nathalie Korboulewsky, Patrick Vallet

5 Irstea, UR EFNO Ecosysèmes Forestiers, Centre de Nogent-sur-Vernisson, F-45290 Nogent-

6 sur-Vernisson, France

7 Corresponding author:

8 Morgane Merlin

$9 \quad$ morgane.merlin@ orange.fr

10 Irstea, UR EFNO Ecosysèmes Forestiers, F-45290 Nogent-sur-Vernisson, France 


\section{Abstract}

The IPCC previsions for the upcoming decades include an increase in frequency and intensity of drought events in several regions worldwide, including Northern Europe. Drought significantly affects forest ecosystems through decreased productivity, increased vulnerability to biotic disturbances and increased subsequent mortality. How forest ecosystems maintain resistance and resilience to drought events are important questions. Our study aimed to assess whether species mixture or an individual tree size within a stand alters a given tree's resilience and resistance to drought. A retrospective study of tree-ring widths allowed us to calculate resistance, resilience and recovery indices for five recent drought events: 1976, the 1990-1992 period, 2003, 2006 and 2010. These drought events were selected based on the SPEI (Standardized Precipitation Evapotranspiration Index) drought index. Our study sample consisted of 108 individual sessile oak (Quercus petraea (Matt.)) or Scots pine (Pinus sylvestris L.) trees sampled in 2012 and 2013 (Orleans forest, central France) in pure and mixed stands, divided into three diameter classes corresponding to three sizes: large, medium and small trees. Scots pine performed better than sessile oak during the 1990-1992 and 2010 droughts while the contrary was observed for the 2003 and 2006 droughts. They performed equally in 1976. We suggest that the differing sensitivity of the two species to spring and summer drought explained this result. In our study, stand composition had no effect on resilience or resistance for either species. The size effect in oaks was unclear as small oaks displayed either a better performance or a worse performance than large oaks. Small pines displayed better resistance and resilience than pines of a larger size. This work stressed the importance of taking into account stand composition and trees size as well as soil and climatic conditions for each drought events to achieve a better understanding of the diversity of responses to climatic variations among forest ecosystems. 
Keywords: drought; resistance; resilience; sessile oak; Scots pine; tree size; stand composition.

\section{Introduction}

In the recent decades, the long term increase in temperature and changes in precipitation patterns (IPCC, 2013) accompanied by an increase in the frequency and intensity of extreme climatic events such as droughts (Smith, 2011) have been the object of several studies. The events are major disturbances, both ecologically and socially. The intense 1976 and 2003 droughts in Europe marked people's minds, and foresters were no exception. They were the first to witness forest decline and tree mortality following these droughts. The ability of forest ecosystems to face such climate changes and extreme events has become a major question for the scientific community. There is a large number of studies addressing this question (Béda $e t$ al., 2006; Allen et al., 2010; Lloret et al., 2012). At the ecosystem level, the composition (Smith, 2011; Cavin et al., 2013), structure and distribution of forests as well as the water, carbon and nutrient cycles are expected to be modified in the context of climate change (Béda et al., 2006; Galiano et al., 2011; Cheaib et al., 2012). Impacts on tree growth and wood production are becoming significant with increasing forest decline and mortality in some parts of Europe, especially in Mediterranean environments (Martinez-Vilalta and Pñol, 2002; Vacchiano et al., 2012; Viłt-Cabrera et al., 2013).

To assess ecosystem stability or species response, three basic aspects can be considered: resistance, recovery and resilience (Grimm and Wissel, 1997). Resistance is the capacity of an ecosystem, species or individual to remain basically unchanged when it is subjected to a disturbance. Recovery is the capacity to regain growth or any other characteristic negatively affected after a disturbance. Resilience is the ability to recover pre-disturbance structures and functions after a disturbance. In the perspective of climate change, these three aspects are 
essential to conserving ecosystems and their functions, or at a smaller scale, species and even individuals.

Ecosystems involve several levels of complexity and diversity. Many studies have examined the benefits of mixed forests (Forrester et al., 2006; Kelty, 2006). Interest in mixed stands is inspired by observations of increased biodiversity in the ecosystem (Felton et al., 2010), better resistance to some biotic disturbances (Jactel and Brockerhoff, 2007; Perot et al., 2013) and an increase in productivity in most cases when compared to monoculture stands (Knoke et al., 2008; Vallet and Perot, 2011). Despite an increasing number of studies relative to mixed stands, we still know little about their functioning compared with pure stands. Niche complementarity, which enables a better use of the available resources - including water, is a common hypothesis to explain increased productivity in mixtures (Lebourgeois et al., 2013). Therefore, studying the potential consequences of climate change - induced modifications in water availability on mixed and monoculture stands is crucial. Two hypotheses could be made for the response of mixed stands to drought. Firstly, mixed stands could improve individual tree species' performance during drought; a species might be mixed with another species which does not occupy the same water reserves. This would lead to a release of intraspecific competition combined with the possibility of facilitation alleviating drought stress through a partitioning of the water reserves between the species (Lebourgeois et al., 2013; Pretzsch et $a l .$, 2013). The involved species would be expected to benefit from this interaction. Secondly and reversely, mixed stands could decrease individual species' performance during drought as it has been observed depending on the tree species and soil conditions. This would result in an increased interspecific competition during drought stress (Jucker et al., 2014). The involved species or the least competitive species would then suffer from mixing during water shortage periods, affecting tree growth and functions such as photosynthesis, transpiration or sap flow (Grossiord et al., 2014). 
Another level of complexity in forest ecosystems lies in the existence of varying individual tree size within a stand. The majority of studies conducted on the impact of drought on forest stands focus on dominant trees, i.e. the largest in diameter with generally more developed crowns and root systems. It is possible to hierarchically organize the trees in an even-aged stand according to their diameter, reflecting differences between individual tree functional statutes within an even-aged stand (Dhôte, 1994). This hierarchy implies a differential availability of resources such as water (Dawson, 1996), nutrients and light (Dhôte, 1994). It also affects the intensity of competition between individuals. Population hierarchy can consequently play an important role in an individual's responses to climatic and biological disturbances (Pichler and Oberhuber, 2007; Martín-Benito et al., 2008; Mérian and Lebourgeois, 2011; Zang et al., 2012). It is important to incorporate both stand composition (pure or mixed stands) and individual tree size in the stand as explanatory variables when studying tree species response to abiotic disturbances such as drought in order to assess the risks associated with climate change and to propose adapted forest management strategies.

We studied the effects of tree size and stand composition on resistance and resilience to drought in terms of radial growth for two species: a deciduous broadleaved species; sessile oak (Quercus petraea Matt.) and a conifer needled species; Scots pine (Pinus sylvestris L.). These two tree species have very different characteristics, suggesting they may have different responses to drought (Bréda et al., 2006; Eilmann et al., 2006; Béda and Badeau, 2008; Michelot et al., 2012a), and are widespread throughout European forests in both pure and mixed stands. Sessile oak is a mesophilic species with a deep root system which prefers semishady environments well adapted to occasional droughts. During periods of water deficit, leaf water potential is reduced, potentially leading to xylem cavitation. The large vessels in oak earlywood are very sensitive to winter embolism (Tyree and Cochard, 1996) and water circulation must be restored each spring by the formation of at least one new tangential row of 
large vessels. Sessile oak is common in Western Europe and is the most widespread species in French forests (National Forest Inventory data). Scots pine is a light-demanding evergreen species. Its root system is more superficial than most broadleaved species but it does develop a strong first pivot and lateral roots. Water potential in the needles is maintained above a threshold level thanks to stomatal closure during periods of water deficit which minimizes the risk of xylem cavitation. Scots pine can stop its radial growth entirely when conditions are too harsh possibly leading to missing tree rings. Its drought tolerance as defined by Niinemets and Valladares (2006) is slightly higher than sessile oak. It is widely distributed throughout temperate and boreal Europe and is common in French forests and around the Mediterranean basin. Both species are present in pure or mixed stands at our study site in the Orkans National Forest in central France.

Radial growth is sensitive to biotic and abiotic disturbances (Lebourgeois et al., 2010; Olivar et al., 2012; Wiley et al., 2013; Palacio et al., 2014). It can be used for past climatic reconstructions or for retrospective analysis of tree performance during past known disturbances (Speer, 2010). We thus used radial growth to evaluate how individual trees responded to past climatic severe events such as drought using indices of resistance, recovery and resilience. We selected five drought events between 1970 and 2013 based on the SPEI (Standardized Precipitation Evapotranspiration Index), a drought index defined by VicenteSerrano et al. (2010). We sought to answer the following three questions:

1. Do sessile oak and Scots pine respond differently to past drought events?

2. Does stand composition (mixed stand versus pure stand) improve or deteriorate individual tree's radial growth during drought events?

3. Does tree status represented by tree size affect individual tree's response to drought?

\section{Material and methods}


For simplification, it is reasonable to partitionate this continuum of tree diameter.Three classes of tree size can thus be distinguished based on diameter: large trees, medium trees and small trees, excluding understorey trees. The study site is located in the center of France, in the Orkans National Forest (France, 4800'N, 209' E) which extends over 35,000 hectares and

Throughout the forest the soil is relatively poor and acidic with a sandy clay-loam texture

(Table 1Erreur ! Source du renvoi introuvable.), and is classified as a planosol (IUSS Working

Group, 2014). Superimposed layers of clay and sand lead to a temporary perched water table in winter, but the low soil water storage capacity reduces available water for plants in minimum temperature of $0.7^{\circ} \mathrm{C}$ in February; mean maximum temperature of $25^{\circ} \mathrm{C}$ in July). The mean annual rainfall is $740 \mathrm{~mm}$ (1969 to 2013 data from the weather station at Nogentsur-Vernisson, France). L., managed in pure or mixed stands.

Table 1. Physico-chemical characteristics of the forest site soil (at 20-40 $\mathrm{cm}$ in depth, mean, standard deviation (s.d.), $n=30$ ). Cation exchange capacity (CEC) is given in milli-equivalents of hydrogen per $100 \mathrm{~g}(\mathrm{meq} / 100 \mathrm{~g})$.

\begin{tabular}{|c|c|c|c|c|c|c|c|c|c|c|}
\hline & $\begin{array}{l}\text { Clay } \\
(\%)\end{array}$ & $\begin{array}{l}\text { Fine } \\
\text { silt } \\
(\%)\end{array}$ & $\begin{array}{c}\text { Coarse } \\
\text { silt } \\
(\%)\end{array}$ & $\begin{array}{c}\text { Fine } \\
\text { sand } \\
(\%)\end{array}$ & $\begin{array}{c}\text { Coarse } \\
\text { sand } \\
(\%)\end{array}$ & $\begin{array}{l}\mathrm{C} \\
(\%)\end{array}$ & $\begin{array}{l}\mathrm{N} \\
(\%)\end{array}$ & $\mathrm{C} / \mathrm{N}$ & $\begin{array}{l}\mathrm{pH}- \\
\mathrm{KCl}\end{array}$ & $\begin{array}{c}\text { CEC } \\
(\mathrm{meq} / 100 \mathrm{~g})\end{array}$ \\
\hline Mean & 8.6 & 11.8 & 7.9 & 14.3 & 55.8 & 0.92 & 0.046 & 19.6 & 4.43 & 4.21 \\
\hline (s.d.) & (2.4) & (2.8) & (2.3) & (2.2) & (7.5) & $(0.25)$ & $(0.010)$ & (2.9) & $(0.16)$ & $(2.58)$ \\
\hline
\end{tabular}


153 Nine plots were selected on three sites in even-aged stands (50 - 80 years old) as part of the

154

155

156

157

158

159

160

161

162

163

164

165

166

167

Oak Pine Tree Mixture Experiment (OPTMix) (Korboulewsky et al., 2013). Each site has one plot of pure sessile oak, one plot of pure Scots pine and one plot with a mixture of the two species. All plots have similar soil conditions, floral compositions, tree age, sylvicultural treatments and diameter distributions (Table 2). For each plot, a 1.5-2 ha area was delimited and the position of each tree was mapped before the individual tree selection process. Nine trees per species and per plot were chosen according to a stratified sampling design with constraints. We studied the following two factors:

- The local composition or mixing rate: the mixing rate in the local environment (a 10mradius circle around each selected tree) was calculated as a percentage of the partial Relative Density Index, or RDI (Reineke, 1933). The calibration for both species of the self-thinning boundaries needed for the RDI calculation followed Charru et al. (2012) based on data from the National Forest Inventory for the northern half of France. In pure stands, the RDI proportion of the target species was $100 \%$. In mixed stands, the RDI of the companion species was set between 40 and $80 \%$ to ensure that the sampled trees from pure and mixed stands had contrasted mixing rates.

- Tree size: this reflects the hierarchy in tree diameter between individual trees, related to the social status within the stand. We distinguished three tree size classes in our study: small trees, medium trees and large trees. Based on 2012 or 2013 tree diameters, the trees at each site were assigned to one of these classes. Understorey trees were excluded. For the selection process, we defined four quantiles from the diameter distribution for each species: $28 \%$ quantile, $38 \%$ quantile, $61 \%$ quantile and $71 \%$ quantile to obtain three intervals clearly separated. Small trees of a given species were sampled in the interval [minimum diameter; $28 \%$ quantile], medium trees were sampled in the interval [38\% quantile; $61 \%$ quantile] and large trees were sampled in the interval [71\% quantile; 
maximum diameter]. However, individual tree-level dynamics may have changed during the growing process due to modifications in the local environment or to genetics, and tree size may also have changed. To refine the influence of the hierarchy on the individuals' responses to each drought event, we redefined the tree size classes for each drought event studied here (see section 2.4 for the selection of the drought events) based on three relative diameter classes (smallest, intermediate, largest) reconstructed from tree ring analyses.

The local density was estimated using the RDI. It was set between 0.5 and 0.75 to ensure similar competition conditions among sample trees. We visually checked the general form of the candidate trees to ensure that the selected trees were representative of the stand population.

The final sample consisted of 108 trees from the two species, the two stand composition types (pure or mixed) and the three tree size classes; three tree replicates per plot were included (Table 2). In autumn 2012 and 2013, the selected trees were felled and a 10cm thick cross section was cut $1.30 \mathrm{~m}$ above the ground, or as close as possible to this level when defects (branches, damage or sap pockets) were present.

Table 2. Mean age and mean diameter at $1.30 \mathrm{~m}$ for each species, stand composition type and tree size class. Age and diameter standard deviation are indicated in parentheses. Nine trees were sampled for each species, stand composition and size. S: small ; M: medium ; L: large.

\begin{tabular}{|c|c|c|c|c|c|c|c|c|c|c|c|c|}
\hline \multirow{3}{*}{$\begin{array}{r}\text { Species } \\
\text { Stand } \\
\text { Size }\end{array}$} & \multicolumn{6}{|c|}{ Sessile oak } & \multicolumn{6}{|c|}{ Scots pine } \\
\hline & \multicolumn{3}{|c|}{ Pure } & \multicolumn{3}{|c|}{ Mixed } & \multicolumn{3}{|c|}{ Pure } & \multicolumn{3}{|c|}{ Mixed } \\
\hline & S & M & $\mathrm{L}$ & S & M & $\mathrm{L}$ & S & M & $\mathrm{L}$ & S & M & $\mathrm{L}$ \\
\hline Age (years) & $\begin{array}{l}63.0 \\
(8.8)\end{array}$ & $\begin{array}{l}65.6 \\
(3.8)\end{array}$ & $\begin{array}{l}65.9 \\
(3.8)\end{array}$ & $\begin{array}{l}65.1 \\
(7.8)\end{array}$ & $\begin{array}{l}68.7 \\
(9.0)\end{array}$ & $\begin{array}{l}72.0 \\
(8.6)\end{array}$ & $\begin{array}{l}55.0 \\
(4.0)\end{array}$ & $\begin{array}{l}56.0 \\
(4.0)\end{array}$ & $\begin{array}{l}56.2 \\
(5.0)\end{array}$ & $\begin{array}{l}57.6 \\
(7.8)\end{array}$ & $\begin{array}{l}61.8 \\
(8.4)\end{array}$ & $\begin{array}{l}68.0 \\
(7.6)\end{array}$ \\
\hline $\begin{array}{r}\text { Diameter } \\
(\mathrm{cm})\end{array}$ & $\begin{array}{l}11.6 \\
(1.5)\end{array}$ & $\begin{array}{l}17.6 \\
(1.9)\end{array}$ & $\begin{array}{l}22.1 \\
(2.2)\end{array}$ & $\begin{array}{l}11.6 \\
(1.8)\end{array}$ & $\begin{array}{l}17.8 \\
(2.4)\end{array}$ & $\begin{array}{c}24 \\
(3.6)\end{array}$ & $\begin{array}{l}21.5 \\
(2.0)\end{array}$ & $\begin{array}{l}27.6 \\
(1.1)\end{array}$ & $\begin{array}{l}30.9 \\
(3.1)\end{array}$ & $\begin{array}{l}18.6 \\
(2.8)\end{array}$ & $\begin{array}{l}26.8 \\
(1.1)\end{array}$ & $\begin{array}{l}33.1 \\
(2.8)\end{array}$ \\
\hline
\end{tabular}




\subsection{Tree-ring analyses}

We used the WinDendro software (Regent, 2005) to measure tree-ring widths from pith to bark along two radii along a systematic north-south axis. The east-west axis was not used to avoid reaction wood or possible ovalization related to the prevailing east-west winds in this region. A visual crossdating was performed for known reference dates: - the 1976 drought and the Diprion pini attack on pine between 1981 and 1986 (Perot et al., 2013). We used a DigiMicro 2.0 Scale USB camera (Mikroskop Digital Kamera, DNT), an SMZ745 wen (Nikon) and an Eclipse E200 microscope (Nikon) to help us clarify the position of a few tree rings close to the pith. Statistical crossdating was performed with the COFECHA software (Grissino-Mayer, 2001).

The following statistics from the COFECHA software output (see Appendix B for detailed result for each sampled tree) were used to verify the quality of the tree-ring series (GrissinoMayer, 2001). Series intercorrelation (SI) is a measure of the strength of the signal common to all the trees sampled. Most chronologies have values between 0.550 and 0.750 . In our sample, SI was 0.577 for oak and 0.631 for pine. These values indicate a good common signal among the individuals sampled. The Expressed Population Signal (EPS) ensures that the trees sampled accurately represent a hypothetical population. This is verified when EPS $>0.85$ (Wigley et al., 1984). This condition was verified in our study with an EPS of 0.96 for sessile oak, and 0.98 for Scots pine.

The analysis was restricted to the 1970-2013 period, which corresponds to the extent of the meteorological data available for the study sites. Moreover, tree growth dynamics are usually different during the juvenile stage and the adult and mature stages. The choice of the 19702013 period ensured that the sampled trees were not in the juvenile stage ( 
Figure 2). Two radial growth variables were calculated. Ring width (RW) per year was calculated as the average ring width over the two radii along the north-south axis. Tree basal area increment (BAI) was calculated per year as follows:

$$
B A I_{n}=\left(d_{n}^{2}-d_{n-1}^{2}\right) \times \pi / 4
$$

where $d_{n}$ is tree diameter for year $n . d_{n}$ was calculated from the cumulative ring widths of the tree ring series for each year.

\subsection{Climatic data and drought index}

Daily minimum, maximum and average temperature and precipitation for the last 44 years (1969-2013) were collected from the Irstea weather station (France, 4750' N, 244' E) located twenty kilometers from the study forest. Drought events were identified based on the SPEI (Standardized Precipitation Evapotranspiration Index) drought index (Vicente-Serrano et al., 2010) calculated with the spei CRAN package. This index has the advantage of incorporating the effects of temperature on drought and considering different time scales indicative of the chronic, long-term or exceptional character of each drought event and can be used to estimate changes in the dynamics and/or intensity of drought events over previous decades. Monthly SPEI is a standardized variable (see Vicente-Serrano et al. (2010) for details of the standardization). It is based on the degree of water surplus or deficit, defined as the difference between the monthly precipitation and the monthly Thornthwaite potential evapotranspiration (Thornthwaite, 1948). In this study, the SPEI for each year was calculated for the growing season spanning seven months from April to October. At this time scale, there is a fairly good correlation between the growth variables (RW for oak and BAI for pine, results not shown) and the SPEI values. When SPEI was under the value of -1 , the year was considered a severe drought year (Potop et al., 2014). Following this criterion, the selected drought events in our study were: 1976, 2006, 2010 and the period 1990-1991-1992 (Figure 1). We added the year 
243

2003 since a short but intense summer drought event occurred then that has been largely studied as an important drought event in Europe (Ciais et al., 2005; Pichler and Oberhuber, 2007; van der Werf et al., 2007; Lebourgeois et al., 2010). Moreover, the SPEI during the summer months of 2003 was considerably below the threshold of -1 , with a value of -2.4 .

Figure 1. SPEI computed for the growing season (April to October) from 1970 to 2013. The selected drought events are indicated by a bold circle. The horizontal dotted line indicates the threshold of -1 below which a drought was considered severe. The 1981 to 1986 period (hatched zone) was removed from our analysis because of severe pine defoliation by Diprion pini.

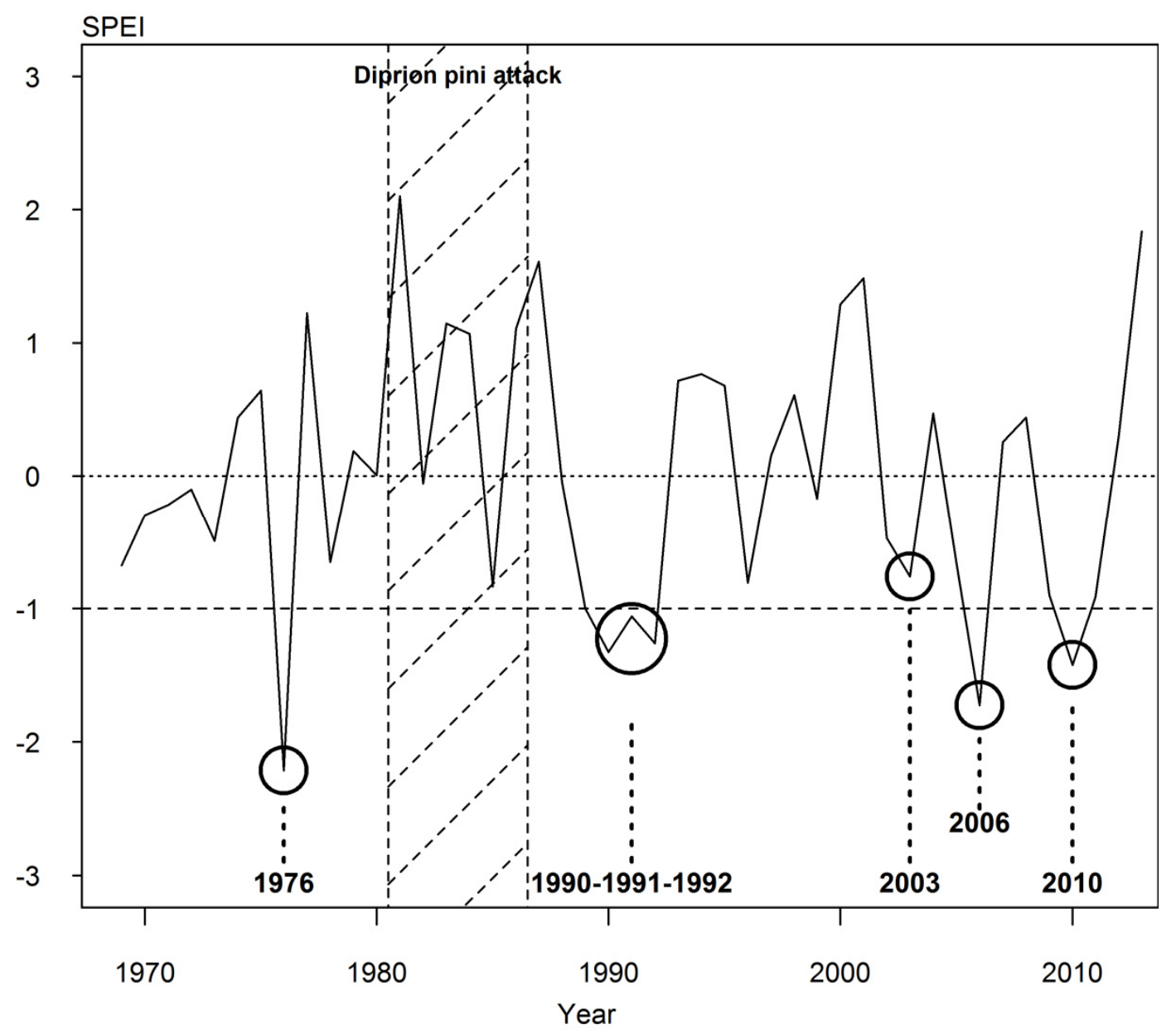

2.5. Resistance, recovery and resilience indices 
254 We used the resistance, recovery and resilience indices defined by Lloret et al. (2011) to

255

256 quantify individual tree responses to the drought events we selected. We hypothesized that pre-disturbance period reflect the expected growth missing during the year of the disturbance. To support this hypothesis, the growth variables on which the indices are based must not show any strong temporal trend, so we used RW for sessile oak and BAI for Scots pine ( Figure 2).

Figure 2. Raw tree-ring growth series for sessile oak and Scots pine according to tree age. Each tree-ring series is printed in grey. The bold line represents the series mean averaged for all trees. (a) for sessile oak; the growth variable presented is RW, (b) for Scots pine: the growth variable presented is BAI. The vertical dotted line indicates the age in 1976 (oldest drought studied here) of the youngest tree sampled.
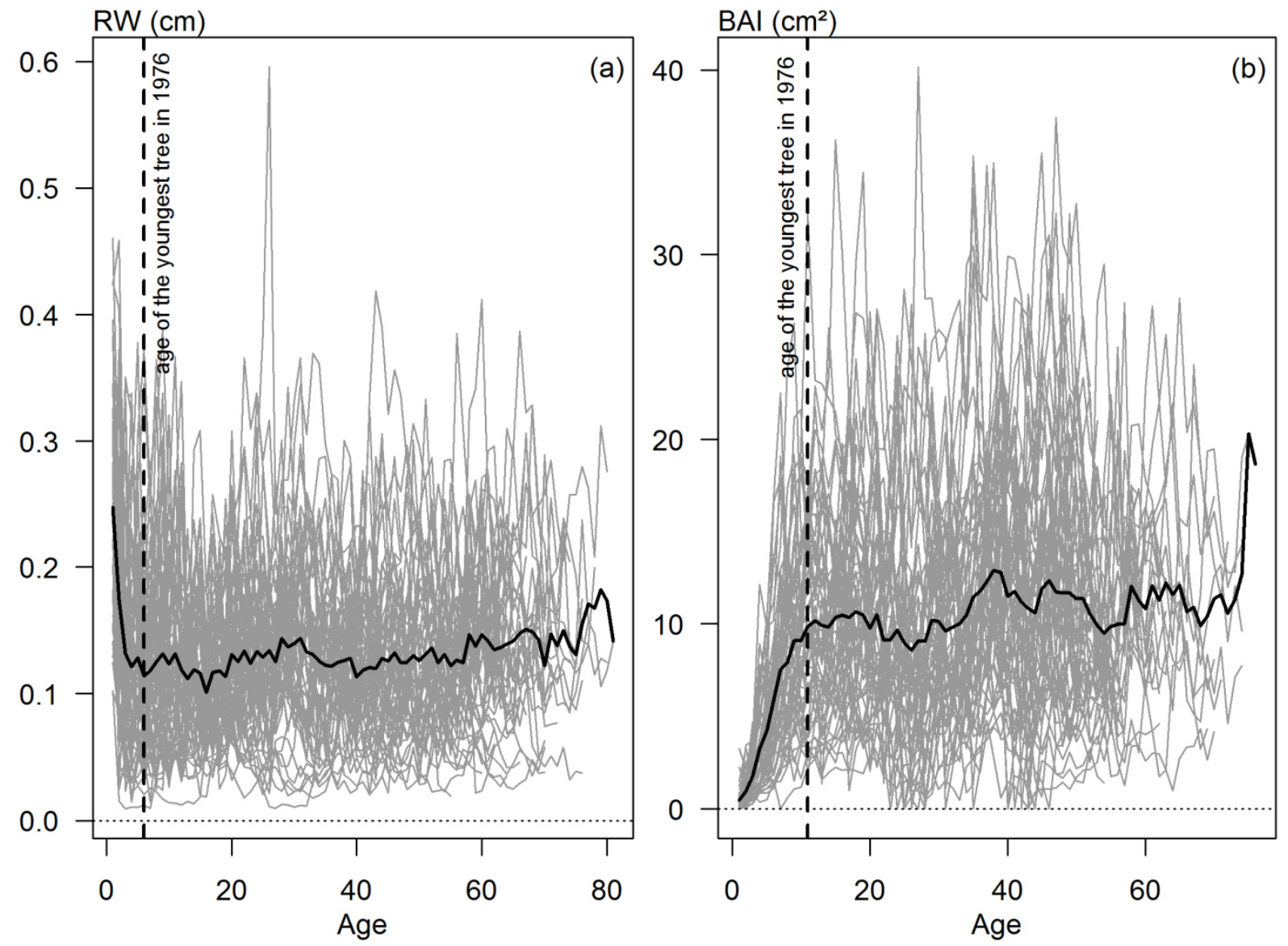
267

268

269

270

271

272

274

The absence of strong age-related trends (excluding the juvenile period) on these two growth variables allowed us to calculate the response indices with raw data (non-transformed or standardized data). Since comparing indices based on two different growth variables could be misleading when interpreting the species responses (see section 2.6 for the statistical models), we quantified the error resulting from using BAI for Scots pine for each drought event. We included a multiplying factor $R$ to link the index calculated with BAI with the one calculated with RW (see Appendix A for further details):

$$
\operatorname{Index}_{B A I}=\text { Index }_{R W} \times R
$$

For the five drought events selected, the relative bias $1-R$ induced by the use of BAI for Scots pine is much smaller (around 4-9\%) than the differences between the oak and pine responses (between 15-36\%) for the same drought events (Appendix A, Figure A 1). The use of different growth indices for the two species does not influence the direction of the results obtained for the comparison of the two species (see Appendix A).

Growth during pre-and post-disturbance periods ( $P r e D r$ and PostDr) was calculated as the average growth in the 3 years respectively before and after disturbance. There is a trade-off between retaining a long enough period to ensure a good estimation of the mean growth before and after the drought event and the risk of an overlap between the pre- or postdisturbance period and adjacent drought events. Growth during disturbance $D r$ is the growth observed the year of the drought event (or the average growth over the period of the disturbance in the case of a drought spanning several years, i.e. 1990 to 1992). Resistance, recovery and resilience are defined as follows (Figure 3):

- Resistance $=\operatorname{Dr} /$ PreDr: the individuals' ability to withstand harsh conditions (e.g. drought). 
- $\quad$ Recovery $=$ PostDr $/ D r$ : the individuals' ability to restore a level of growth after disturbance relative to the damage during the disturbance.

- Resilience $=$ PostDr/PreDr: the ability of an individual to regain postdisturbance growth similar to pre-disturbance growth.

Figure 3. Resistance Rt, recovery Rc and resilience Rs indices in a hypothetical case, adapted (solid line) corresponds to the positive slope.

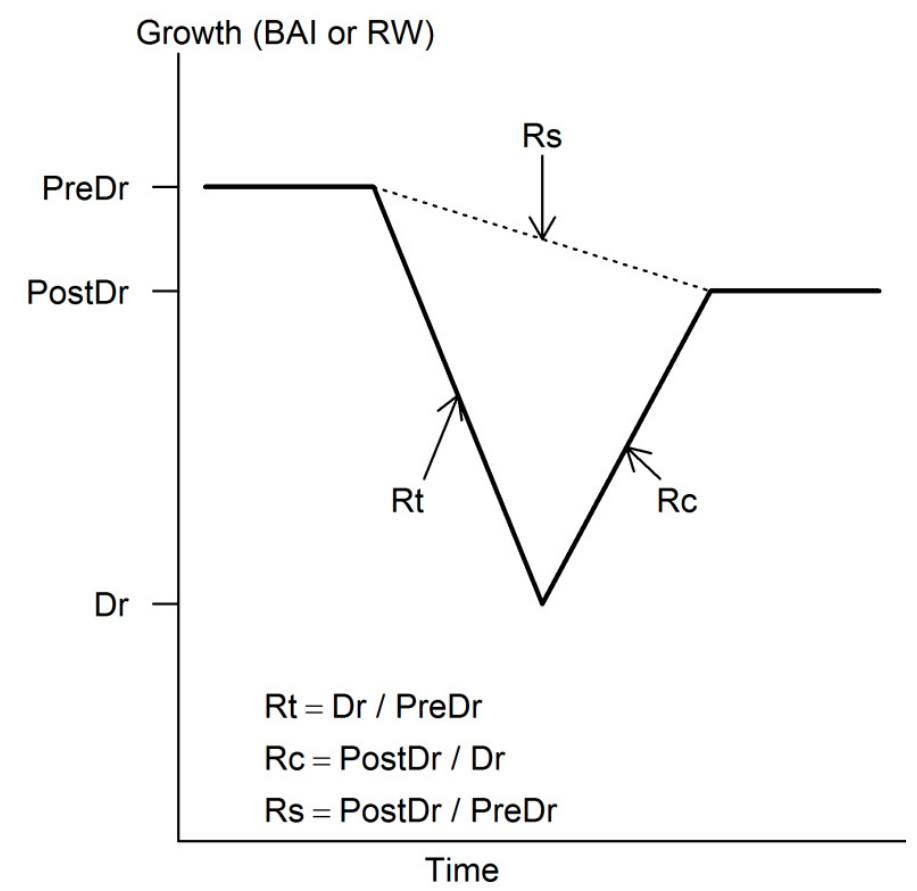

The post-disturbance period for 2003 and the pre-disturbance period for 2006 overlap. We therefore decided to use the 2006 post-disturbance period to calculate the 2003 indices and the 2003 pre-disturbance period for the 2006 indices. This choice removes the immediate impact on growth of the 2003 drought event on individual tree responses to the 2006 drought. It should also be noted that resilience for the 2010 drought event is incomplete for the trees sampled in 2012 as only two years of data were available after the drought event to calculate the resilience index for these trees. 
Our first question on species specific response to drought was tested for each drought event. reference:

$$
I_{i j k}=m+m_{i}+E_{j}+\varepsilon_{i j k}
$$

where $I_{i j k}$ is one of the three indices calculated for a tree $k$ of a species $j$ in plot $i, m$ is the intercept representing the sessile oak average for the relevant index and year; $m_{i}$ is the plot random effect; $E_{j}$ is the species effect (i.e. the difference for the relevant index and year between Scots pine and the reference - sessile oak) and $\varepsilon_{i j k}$ are the residuals of the model. For each drought event, the species effect was removed in the model if it was found to be not significant.

We also used linear mixed models to answer our second and third questions on stand composition and tree size effects on individual's performance during drought events for each species and each drought event. The dependent variables were the indices of response to drought (log-transformed when necessary). The explanatory variables were stand composition (mixed or pure, fixed effect), tree size (large, medium and small, fixed effect) and plot (random effect). The full linear mixed model used to test the effects of composition and tree size for a given drought event and one species was as follows, with large trees growing in pure stands as the reference:

$$
I_{i j k l}=m+m_{i}+C_{j}+S_{k}+C S_{j k}+\varepsilon_{i j k l}
$$


where $I_{i j k l}$ is one of the three indices calculated for a tree $l$ belonging to a size $k$ in composition $j$ for the plot $i, m$ is the intercept representing the reference (large trees growing in pure stands) average for the relevant index and year; $m_{i}$ is the plot random effect; $C$ is the composition effect (i.e. the difference between the reference - pure - and mixed stands); $S$ corresponds to the tree size parameter (i.e. the difference between the reference - large - and each of the other two size classes); CS is the interaction between composition and size; and $\varepsilon_{i j k l}$ are the residuals of the model. For each model, variables which were found to be not significant were removed to improve the estimations of the significant variables. The interaction parameter $C S$ was consequently removed from all models as it was never significant. All statistical analyses were performed with the nlme package of the R statistical software (R Development Core Team, 2014). The significance threshold was set at 0.05.

\section{Results}

Growth decreased during the drought events for both sessile oak and Scots pine as resistance values were less than 1 in average (Table 3). Mean index values showed relatively high levels of resistance to drought and resilience for both species (Table 3).

Table 3. Mean values (and standard deviation s.d.) of the resistance, recovery and resilience indices. Mean values are calculated for each species over the five selected drought events.

\begin{tabular}{rcccccc} 
& \multicolumn{2}{c}{ Resistance Rt } & \multicolumn{2}{c}{ Recovery Rc } & \multicolumn{2}{c}{ Resilience Rs } \\
\cline { 2 - 7 } & Oak & Pine & Oak & Pine & Oak & Pine \\
\hline Mean & 0.759 & 0.787 & 1.361 & 1.366 & 0.994 & 0.985 \\
s.d. & 0.218 & 0.274 & 0.606 & 0.765 & 0.434 & 0.457
\end{tabular}

3.1. Comparison between the two species' response to drought events

The species effect was significant for some drought events, and differs depending on the index. Pine was more resistant than oak for 1990-1992 and 2010 droughts and more resilient 
346 for the 1990-1992 drought only. Oak was more resistant for the 2003 and 2006 droughts,

347 recovered better after the 2010 drought (Table 4Erreur ! Source du renvoi introuvable.).

348 Table 4. Results from the linear mixed models for species effect on resistance Rt, recovery Rc

349 and resilience Rs indices for the five selected drought events. For each model, when the

350 "species" variable was not significant, we chose to remove it completely. Parameters are

351 estimated with sessile oak as the reference. In below a drought event indicates that logarithm

352 transformation of the response variable was used to fit the model. The estimates and standard

353 deviations (s.d.) were not back transformed when the logarithm was applied. Significant

354 results are shown in bold characters. Shading indicates the direction of the difference between

355 Scots pine and the reference, i.e. sessile oak; dark grey: positive difference; light grey:

356 negative difference.

\begin{tabular}{|c|c|c|c|c|c|c|}
\hline & & 1976 & 1990-1992 & 2003 & 2006 & 2010 \\
\hline $\mathbf{R t}$ & & & $\ln$ & & $\ln$ & $\ln$ \\
\hline \multirow{3}{*}{ Intercept } & Estimation & 0.668 & -0.405 & 0.951 & -0.307 & -0.305 \\
\hline & & 0.018 & 0.038 & 0.034 & 0.057 & 0.043 \\
\hline & $p$-value & $<0.001$ & $<0.001$ & $<0.001$ & $<0.001$ & $<0.001$ \\
\hline \multirow{3}{*}{ Scots pine } & Estimation & & 0.257 & -0.155 & -0.345 & 0.275 \\
\hline & & & 0.054 & 0.041 & 0.066 & 0.051 \\
\hline & p-value & & $<0.001$ & $<0.001$ & $<0.001$ & $<0.001$ \\
\hline Re & & $\ln$ & $\ln$ & $\ln$ & $\ln$ & $\ln$ \\
\hline \multirow{3}{*}{ Intercept } & Estimation & 0.514 & 0.336 & 0.123 & 0.320 & -0.272 \\
\hline & & 0.073 & 0.035 & 0.038 & 0.057 & 0.066 \\
\hline & $\mathrm{p}$-value & $<0.001$ & $<0.001$ & 0.002 & $<0.001$ & $<0.001$ \\
\hline \multirow{3}{*}{ Scots pine } & Estimation & & & & 0.235 & -0.172 \\
\hline & & & & & 0.059 & 0.051 \\
\hline & $\mathrm{p}$-value & & & & $<0.001$ & $<0.001$ \\
\hline Rs & & $\ln$ & $\ln$ & $\ln$ & $\ln$ & $\ln$ \\
\hline \multirow{3}{*}{ Intercept } & Estimation & 0.087 & -0.091 & -0.046 & -0.046 & -0.526 \\
\hline & s.d. & 0.056 & 0.061 & 0.038 & 0.038 & 0.076 \\
\hline & $\mathrm{p}$-value & 0.126 & 0.134 & 0.236 & 0.236 & $<0.001$ \\
\hline \multirow{3}{*}{ Scots pine } & Estimation & & 0.287 & & & \\
\hline & s.d. & & 0.074 & & & \\
\hline & $p$-value & & $<0.001$ & & & \\
\hline
\end{tabular}


359 The effect of stand composition (pure or mixed stands) on sessile oak or Scots pine responses

360 was never significant for the selected drought events and was thus removed from all models

$361 \quad$ (Table 
362

363

364

365

Table 6. Results from the linear mixed models for stand composition and tree size effects on resistance Rt, recovery Rc and resilience Rs indices of Scots pine for the five selected drought events. Parameters are estimated with pure stands and large trees as the references. In below a drought event indicates that logarithm transformation of the response variable was used to fit the model. Estimates and standard deviations (s.d.) were not back transformed when the logarithm was applied. Significant results are shown in bold characters. Shading indicates the direction of the difference between each factor level and the references, i.e. large trees and pure stands; dark grey: positive difference; light grey: negative difference. ) .

\subsection{Effects of tree size on species responses to drought events}

\subsubsection{Sessile oak}

The effect of the tree size on the sessile oak response to drought was variable depending on the year and the index considered. In 2003, 2006 and 2010, small trees showed significantly lower resistance $(2003)$ or recovery $(2006,2010)$ than did large trees. The opposite result was found for resistance for the 1990-1992 drought event (Table 5,

Figure 4). There was no effect of tree size on sessile oak resilience for any of the five drought events considered.

\subsubsection{Scots pine}

Several significant results were found. The general trend for Scots pine indicates better resistance and resilience among small individuals than among large individuals ( 
382 Table 6. Results from the linear mixed models for stand composition and tree size effects on

383 resistance Rt, recovery Rc and resilience Rs indices of Scots pine for the five selected drought

384 events. Parameters are estimated with pure stands and large trees as the references. In below a

385 drought event indicates that logarithm transformation of the response variable was used to fit

386 the model. Estimates and standard deviations (s.d.) were not back transformed when the

387 logarithm was applied. Significant results are shown in bold characters. Shading indicates the

388 direction of the difference between each factor level and the references, i.e. large trees and

389 pure stands; dark grey: positive difference; light grey: negative difference.

390 , Figure 5). There were no significant effects of stand composition or tree size for some indices

and

drought

events 
392 Table 6. Results from the linear mixed models for stand composition and tree size effects on

393 resistance Rt, recovery Rc and resilience Rs indices of Scots pine for the five selected drought

394 events. Parameters are estimated with pure stands and large trees as the references. In below a

395 drought event indicates that logarithm transformation of the response variable was used to fit

396 the model. Estimates and standard deviations (s.d.) were not back transformed when the

397 logarithm was applied. Significant results are shown in bold characters. Shading indicates the

398 direction of the difference between each factor level and the references, i.e. large trees and

399 pure stands; dark grey: positive difference; light grey: negative difference.

$400 \quad)$. 
401 Table 5. Results from the linear mixed models for stand composition and tree size effects on 402 resistance $\mathrm{Rt}$, recovery $\mathrm{Rc}$ and resilience $\mathrm{Rs}$ indices of sessile oak for the five selected 403 drought events. Parameters are estimated with pure stands and large trees as the references. In 404 below a drought event indicates that logarithm transformation of the response variable was 405 used to fit the model. Estimates and standard deviations (s.d.) were not back transformed 406 when the logarithm was applied. Significant results are shown in bold characters. Shading indicates the direction of the difference between each factor level and the references, i.e. large trees and pure stands; dark grey: positive difference; light grey: negative difference.

\begin{tabular}{|c|c|c|c|c|c|c|c|}
\hline & & & 1976 & $\begin{array}{r}1990- \\
1992 \\
\end{array}$ & 2003 & 2006 & 2010 \\
\hline $\mathbf{R t}$ & & & & $\ln$ & & & $\ln$ \\
\hline \multirow{11}{*}{ Composition } & & Estimates & 0.654 & -0.537 & 1.041 & 0.732 & -0.304 \\
\hline & & & 0.022 & 0.059 & 0.063 & 0.023 & 0.062 \\
\hline & & $\mathrm{p}$-value & $<0.001$ & $<0.001$ & $<0.001$ & $<0.001$ & $<0.001$ \\
\hline & & Estimates & & & & & \\
\hline & Mixed & $\begin{array}{r}\text { s.d. } \\
\text { p-value }\end{array}$ & & & & & \\
\hline & & Estimates & & 0.155 & -0.121 & & \\
\hline & Medium & s.d. & & 0.071 & 0.063 & & \\
\hline & & $\mathrm{p}$-value & & 0.034 & 0.059 & & \\
\hline & & Estimates & & 0.241 & -0.130 & & \\
\hline & Small & & & 0.071 & 0.063 & & \\
\hline & & $\mathrm{p}$-value & & 0.001 & 0.043 & & \\
\hline Rc & & & $\ln$ & & $\ln$ & & \\
\hline \multirow{4}{*}{ Intercept } & & Estimates & 0.624 & 1.443 & 0.086 & 1.572 & 0.850 \\
\hline & & & 0.090 & 0.071 & 0.062 & 0.079 & 0.064 \\
\hline & & $\mathrm{p}$-value & $<0.001$ & $<0.001$ & 0.175 & $<0.001$ & $<0.001$ \\
\hline & & Estimates & & & & & \\
\hline \multirow[t]{3}{*}{ Composition } & Mixed & $\begin{array}{r}\text { s.d. } \\
\text { p-value }\end{array}$ & & & & & \\
\hline & & Estimates & & & & -0.262 & -0.068 \\
\hline & Medium & s.d. & & & & 0.090 & 0.043 \\
\hline \multirow{4}{*}{ Size } & & $\mathrm{p}$-value & & & & 0.005 & 0.117 \\
\hline & & Estimates & & & & -0.129 & -0.125 \\
\hline & Small & & & & & 0.090 & 0.043 \\
\hline & & $\mathrm{p}$-value & & & & 0.157 & 0.005 \\
\hline Rs & & & $\ln$ & $\ln$ & & & $\ln$ \\
\hline \multirow{4}{*}{ Intercept } & & Estimates & 0.169 & -0.070 & 1.052 & 1.052 & -0.573 \\
\hline & & & 0.010 & 0.062 & 0.063 & 0.063 & 0.106 \\
\hline & & $p$-value & 0.098 & 0.271 & $<0.001$ & $<0.001$ & $<0.001$ \\
\hline & & Estimates & & & & & \\
\hline Composition & Mixed & $\begin{array}{r}\text { s.d. } \\
\text { p-value }\end{array}$ & & & & & \\
\hline Size & Medium & $\begin{array}{r}\text { Estimates } \\
\text { s.d. }\end{array}$ & & & & & \\
\hline
\end{tabular}


Author-produced version of the article published in Forest ecology and management, 2015, vol 339, p. 22-33, doi:10.1016/j.foreco.2014.11.032

The original publication is available at : http://www.sciencedirect.com/science/article/pii/S037811271400700

p-value

Estimates

Small s.d.

p-value

409 
Table 6. Results from the linear mixed models for stand composition and tree size effects on

411 resistance Rt, recovery Rc and resilience Rs indices of Scots pine for the five selected drought

412 events. Parameters are estimated with pure stands and large trees as the references. In below a

413 drought event indicates that logarithm transformation of the response variable was used to fit

414 the model. Estimates and standard deviations (s.d.) were not back transformed when the

415 logarithm was applied. Significant results are shown in bold characters. Shading indicates the

416 direction of the difference between each factor level and the references, i.e. large trees and

417 pure stands; dark grey: positive difference; light grey: negative difference.

\begin{tabular}{lrrrrrr} 
& & $\mathbf{1 9 7 6}$ & $\mathbf{1 9 9 0 -}$ & $\mathbf{2 0 0 3}$ & $\mathbf{2 0 0 6}$ & $\mathbf{2 0 1 0}$ \\
\hline \multirow{2}{*}{ Rt } & & & \multicolumn{1}{c}{$l n$} \\
& & & & & \multicolumn{1}{c}{$l n$} \\
\multirow{3}{*}{ Intercept } & Estimates & $\mathbf{0 . 6 0 7}$ & $\mathbf{- 0 . 1 4 8}$ & $\mathbf{0 . 7 9 0}$ & $\mathbf{0 . 4 8 1}$ & -0.029 \\
& s.d. & $\mathbf{0 . 0 4 5}$ & $\mathbf{0 . 0 5 8}$ & $\mathbf{0 . 0 2 2}$ & $\mathbf{0 . 0 5 9}$ & 0.032 \\
& p-value & $<\mathbf{0 . 0 0 1}$ & $\mathbf{0 . 0 1 4}$ & $<\mathbf{0 . 0 0 1}$ & $<\mathbf{0 . 0 0 1}$ & 0.367 \\
\cline { 2 - 8 }
\end{tabular}

\begin{tabular}{|c|c|c|c|c|c|c|c|}
\hline Composition & Mixed & $\begin{array}{r}\text { Estimates } \\
\text { s.d. } \\
\text { p-value }\end{array}$ & & & & & \\
\hline \multirow{6}{*}{ Size } & \multirow{3}{*}{ Medium } & Estimates & \multicolumn{2}{|l|}{0.088} & \multicolumn{3}{|c|}{0.105} \\
\hline & & & \multirow{2}{*}{\multicolumn{2}{|c|}{$\begin{array}{r}0.052 \\
0.095\end{array}$}} & \multicolumn{3}{|c|}{0.065} \\
\hline & & p-value & & & \multicolumn{3}{|c|}{0.112} \\
\hline & \multirow{3}{*}{ Small } & Estimates & \multicolumn{2}{|l|}{0.128} & \multicolumn{3}{|c|}{0.137} \\
\hline & & s.d. & 0.052 & & \multirow{2}{*}{\multicolumn{3}{|c|}{$\begin{array}{r}0.065 \\
0.041\end{array}$}} \\
\hline & & p-value & 0.017 & & & & \\
\hline Rc & & & $\ln$ & $\ln$ & & & $\ln$ \\
\hline \multirow{3}{*}{ Intercept } & & Estimates & 0.425 & 0.334 & 1.220 & 1.801 & -0.450 \\
\hline & & & 0.085 & 0.044 & 0.058 & 0.126 & 0.091 \\
\hline & & p-value & $<0.001$ & $<0.001$ & $<0.001$ & $<0.001$ & $<0.001$ \\
\hline
\end{tabular}

\begin{tabular}{|c|c|c|c|c|c|c|c|}
\hline \multirow[t]{3}{*}{ Composition } & Mixed & $\begin{array}{r}\text { Estimates } \\
\text { s.d. } \\
\text { p-value } \\
\end{array}$ & & & & & \\
\hline & & Estimates & & & & & \\
\hline & Medium & s.d. & & & & & \\
\hline \multirow{3}{*}{ Size } & & $\mathrm{p}$-value & & & & & \\
\hline & & Estimates & & & & & \\
\hline & Small & $\begin{array}{r}\text { s.d. } \\
\text { p-value }\end{array}$ & & & & & \\
\hline $\mathbf{R s}$ & & & $\ln$ & $\ln$ & $\ln$ & $\ln$ & $\ln$ \\
\hline \multirow[b]{2}{*}{ Intercept } & & Estimates & -0.220 & 0.186 & -0.288 & -0.253 & -0.479 \\
\hline & & $\begin{array}{r}\text { s.d. } \\
\text { p-value }\end{array}$ & $\begin{array}{r}0.070 \\
0.003\end{array}$ & $\begin{array}{r}0.092 \\
0.049\end{array}$ & $\begin{array}{r}0.080 \\
0.001\end{array}$ & $\begin{array}{r}0.081 \\
0.003\end{array}$ & $\begin{array}{r}0.100 \\
<0.001\end{array}$ \\
\hline
\end{tabular}

Composition $\begin{array}{r}\text { Mixed } \begin{array}{r}\text { Estimates } \\ \text { s.d. } \\ \text { p-value }\end{array} \\ \hline\end{array}$




\begin{tabular}{|c|c|c|c|c|c|}
\hline \multirow{6}{*}{ Size } & \multirow{3}{*}{ Medium } & Estimates & \multirow{2}{*}{$\begin{array}{r}0.323 \\
0.089\end{array}$} & \multirow{2}{*}{$\begin{array}{c}0.219 \\
0.113\end{array}$} & \multirow{2}{*}{$\begin{array}{r}0.149 \\
0.115\end{array}$} \\
\hline & & s.d. & & & \\
\hline & & p-value & $<0.001$ & 0.059 & 0.203 \\
\hline & \multirow{3}{*}{ Small } & Estimates & 0.337 & 0.310 & 0.275 \\
\hline & & & 0.089 & 0.113 & 0.115 \\
\hline & & $\mathrm{p}$-value & $<0.001$ & 0.009 & 0.021 \\
\hline
\end{tabular}

419 Figure 4. Difference between the resistance or resilience index value for large sessile oak trees 420 and the values for the other tree size classes for each drought event. For each year and tree 421 size, the segments and stars indicate the level of significance of the difference between large 422 Scots pine trees and other trees from the models. The models were re-run with the medium size as the reference to test the difference between this size and the small size. $*$ : $\mathrm{p}<0.05 ; * *$ : $\mathrm{p}<0.01 ; * * *: \mathrm{p}<0.001$; ns: not significant.
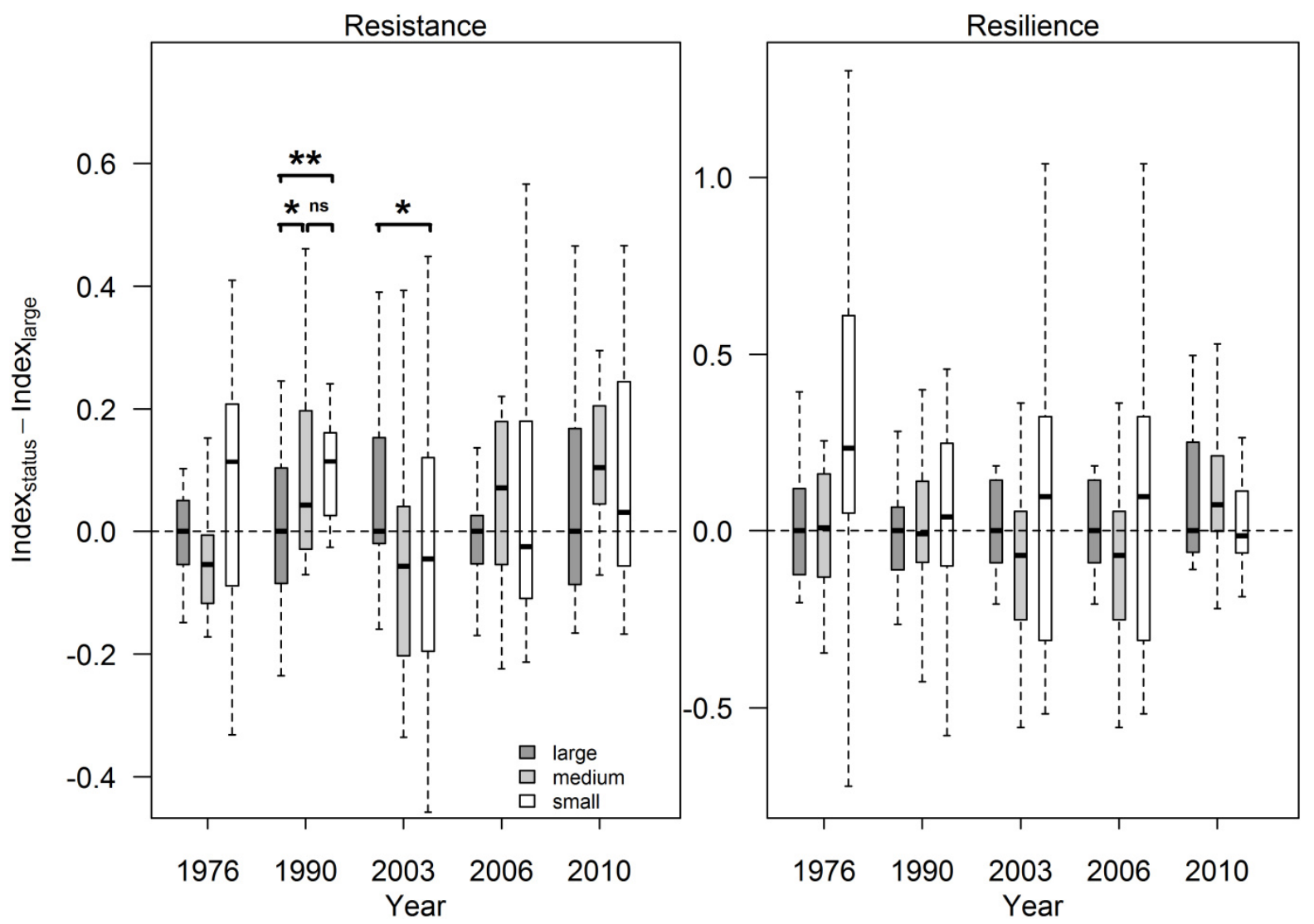

Figure 5. Difference between the resistance or resilience index value for large Scots pine trees 427 and the values for the other tree size classes for each drought event. For each year and tree 
size, the segments and stars indicate the level of significance of the difference between large Scots pine trees and other trees from the models. The models were re-run with the medium size as the reference to test the difference between this size and the small size. $*$ : $p<0.05 ; * *$ : $\mathrm{p}<0.01 ; * * *: \mathrm{p}<0.001$; ns: not significant.
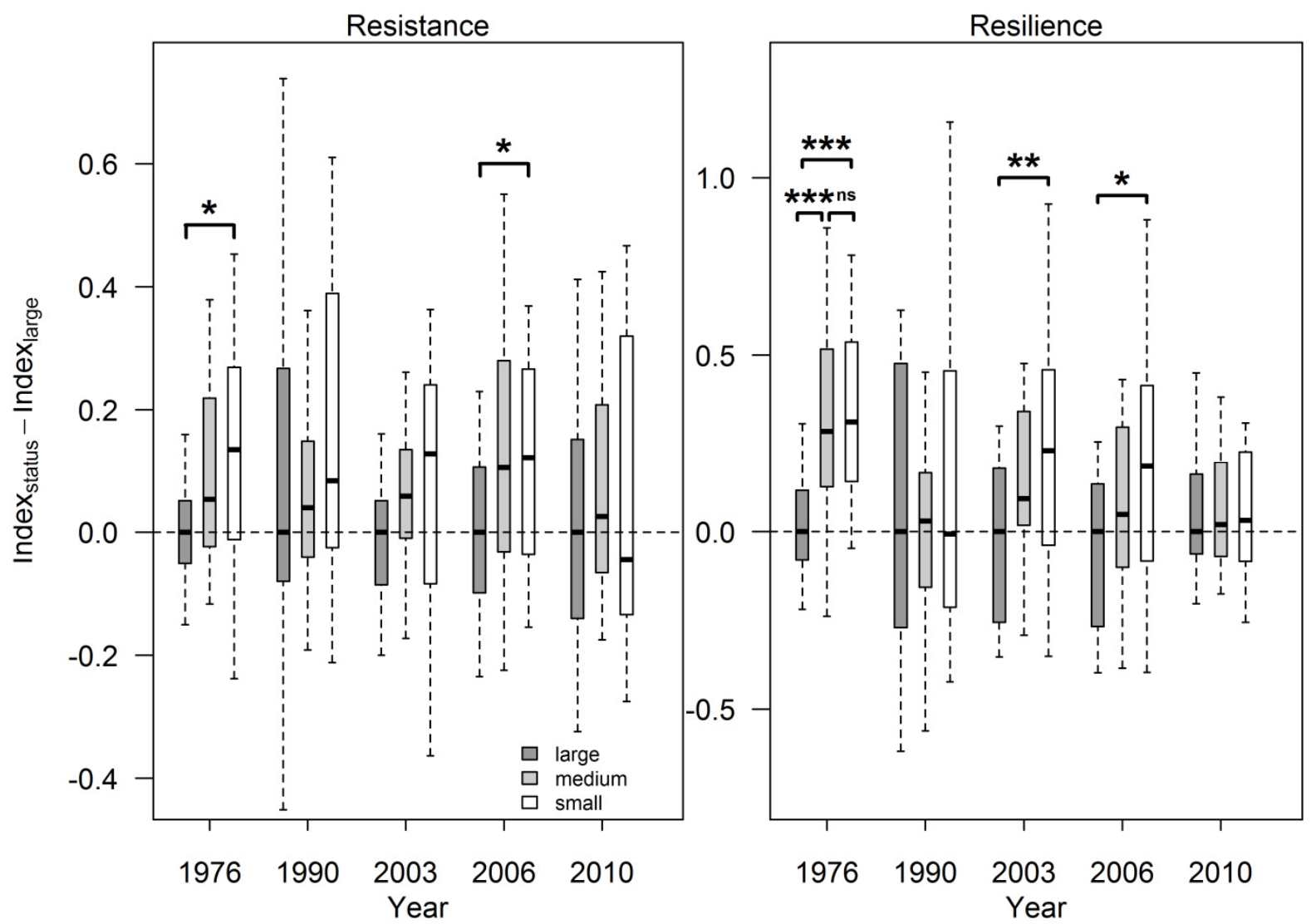

433

434

435

\section{Discussion}

As expected, both species reduced their radial growth during drought events. When drought occurs, photosynthesis is reduced leading to less carbon available for functions such as radial growth which in turn decreases (Chaves et al., 2003; Palacio et al., 2014).

Resistance and resilience to drought differed between oak and pine, as expected (Table 4), though the mean values for each species were close to each other (Table 3). Stand composition had no effect on the resistance indices of the species studied (Table 5, Table 6). However, tree size did have an effect in some cases. The influence of tree size was 
441 pronounced and unidirectional for resistance and resilience in Scots pine for several drought

442 events. Results for sessile oak show that the size effect varied between drought events or 443 indices.

445 We first showed that sessile oak and Scots pine responded differently to the five drought 446 events studied. Pine was more resistant during the 1990-1992 drought period and the 2010 447 drought while oak was more resistant during the 2003 and 2006 droughts. The drought events 448 studied here occurred at different periods during the growing season and this could have 449 influenced the responses of the two species. Indeed, several studies have shown that pine and 450 oak species have different growth dynamics during the growing season (Weber et al., 2007; 451 Eilmann et al., 2009; Michelot et al., 2012b). Complementary analyses of the SPEI over the spring (March to May) and summer months (June to August) separately revealed different types of drought (Figure 6). 
Figure 6. SPEI computed for spring (April to June) and for summer (July to August) from 1970 to 2013. The selected drought events are indicated by a bold circle. The horizontal dotted line indicates the threshold of -1 below which a drought was considered severe. The 1981 to 1986 period (hatched zone) was removed from our analysis because of severe pine defoliation by Diprion pini.
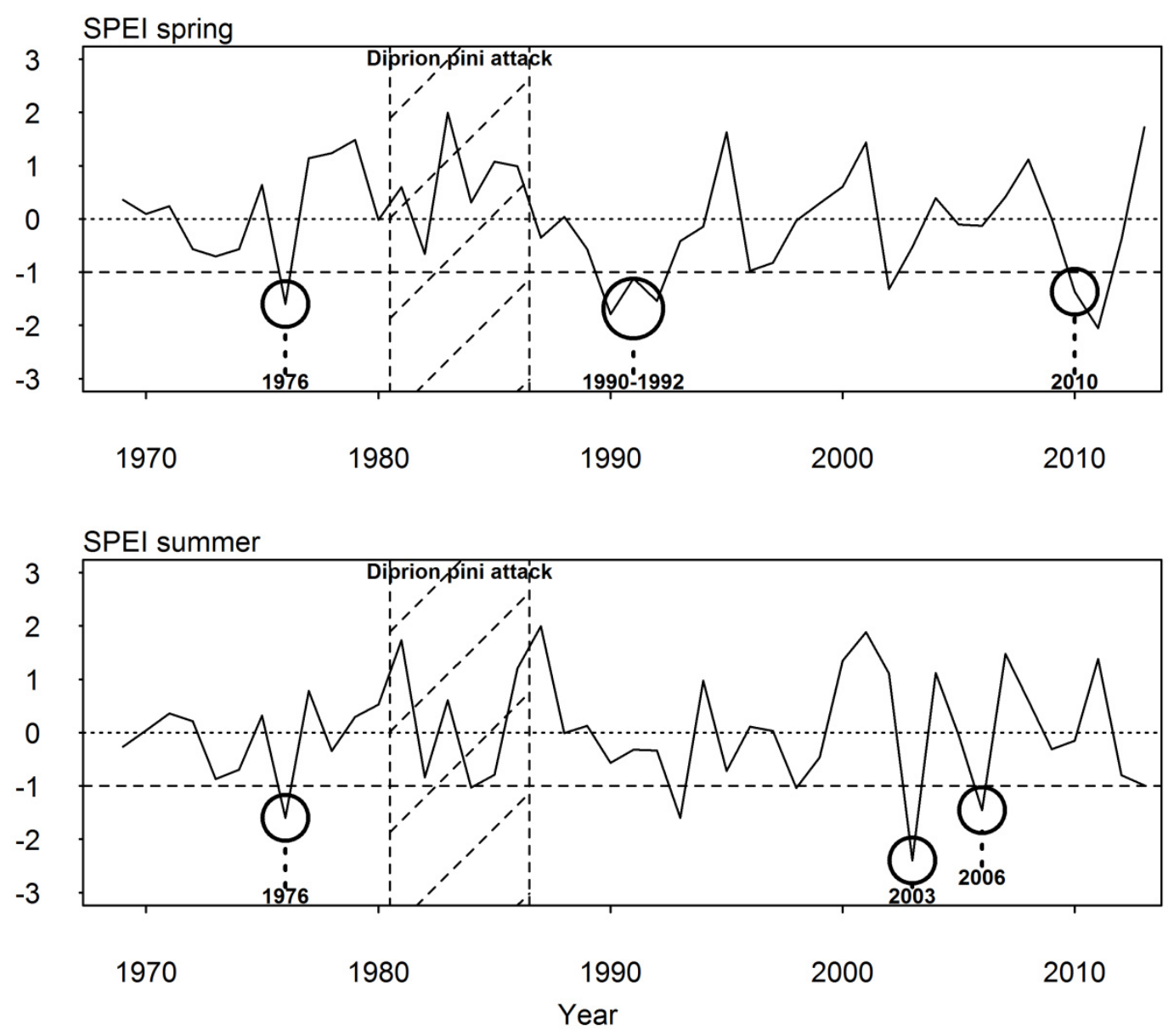

The 1976 drought was global throughout the whole growing season. The 1990-1992 and 2010 droughts occurred in the spring while the 2003 and 2006 droughts were intense summer droughts. Our results suggest that Scots pine was more resistant during spring droughts than sessile oak, and that sessile oak was more resistant during summer droughts (Table 4). The 1976 drought, which lasted through spring and summer, should have affected both species; our results confirm this (we found no difference between the two species for any index, Table 
how the two species form intra-annual wood, could explain this time-dependent resistance. Zweifel et al. (2006) showed that pubescent oak (Quercus pubescens) starts radial growth about one month before leaf expansion, achieving almost half of the annual radial increment by the time the leaves reach full expansion at the end of spring. Furthermore, oak species have been found to be more sensitive to spring conditions, and particularly to water availability during spring, than to summer conditions and droughts (van der Werf et al., 2007; Weber et al., 2007; Eilmann et al., 2009; Zang et al., 2012; Morán-López et al., 2014). Earlywood vessels in oak are formed before and during budburst using stored reserves from the previous growing season (Corcuera et al., 2004). These newly formed vessels are wide allowing such ringporous species to transport more water during early growing season but at the expense of increased embolism risk.They rapidly become embolized as conditions become more stressful during the growing season (Cochard and Tyree, 1990). During spring droughts, the oak's newly formed vessels are exposed to the risk of cavitation leading to water deficit and reduced cell enlargement. Water stress during spring is thus the most important factor controlling radial growth for oak (Tardif and Conciatori, 2006). This phenomenon constrains ring width despite the potential activation of drought avoidance mechanisms (Eilmann et al., 2009). In contrast, summer drought would be of less consequence on oak radial growth as the radial increment would have mainly occurred during the months preceding the drought. However, a summer drought still reduces photosynthesic activity for oak through stomatal closure, which prevents further accumulation of reserves for the following year's growth (Chaves et al., 2003). For Scots pine, on the other hand, needles only appear during the summer and the tree has achieved a mere fourth of its annual radial increment by the time needles reach full expansion (Zweifel et al., 2006). This species' radial growth dynamics, which have been extensively studied in Europe, show a stronger dependency on conditions at the end of spring and during the summer months (Weber et al., 2007; Eilmann et al., 2009; 
492 Eilmann et al., 2011; Zang et al., 2012; Taeger et al., 2013). Spring droughts constrain pine

493

494

495

496

497

498

499

500

501

502

503

504

505

506

507

508

509

510

511 growth and might lead to the cavitation of some xylem tracheids. However, pine can continue its radial growth when the conditions become better after the spring drought subsides, resulting in wider ring widths during spring drought years than for oak. Summer droughts, on the other hand, quite strongly affect pine growth because they hamper needle formation and reduce cell enlargement, consequently reducing the radial increment for that year, in contrast to oak.

Results for recovery were less pronounced than for resistance: for resistance, four out of five drought events showed significant differences between the two species while only two out of five drought events showed significant differences for recovery (Table 4). However, assuming that both resistance to and recovery from drought events depend on the amount of carbon reserves available, a compromise might be established between these two indices (Galiano et al., 2011; Lloret et al., 2011). As mentioned before, ring widths for oak show a strong relationship with climatic conditions of the previous year, even when the current year's conditions are favorable (Zweifel et al., 2006; van der Werf et al., 2007; Eilmann et al., 2009; Michelot et al., 2012b). A summer drought does not constrain oak ring width but does constrain its photosynthetic activity, thus reducing the amount of reserves stored for the establishment of the following year's tree ring. This was observed for 2004, following the 2003 drought, for some individuals in our study (data not shown) and for 2007, following the 2006 drought (van der Werf et al., 2007). The longer growing season for Scots pine (Michelot et al., 2012b) as well as its ability to maintain photosynthesis throughout autumn and winter thanks to its evergreen leaves limit its dependence on the previous year's accumulated reserves for recovery after a drought event (Gruber et al., 2012). This compromise between resistance and recovery explains that in 2006 (summer drought) and 2010 (spring drought), we found opposite results for resistance and resilience (Table 4). However, this idea of a 
517 potential compromise between resistance and recovery based on the amount of carbon 518 reserves available needs further investigation.

Neither pine nor oak responses to the selected drought events depended on stand composition

521 (pure or mixed) (Table 5). This result was unexpected as results in the literature usually

522 present various effects of species mixtures in forests in case of biotic and abiotic disturbances, whether they present benefits or drawbacks (Knoke et al., 2008; Maestre et al., 2009; Felton et al., 2010; Lebourgeois et al., 2013; Perot et al., 2013; Pretzsch et al., 2013).

Assuming equivalent stand density, lower growth in mixed stands associated to drought episodes would indicate stronger between-species competition (Grossiord et al., 2014) than within-population competence. The absence of this pattern in our results indicates that drought conditions did not increase between-species competition, suggesting that water acquisition for each species was not disrupted by the presence of the other species. The absence of any benefits (higher growth) of the mixed stands also suggests the absence of any complementarity process (through root stratification for example e. g. Pretzsch et al. (2013)) in our study sites during drought, which might be related to the type of soil encountered in the study plots prohibiting deep root extension (Table 1).

Moreover, the trees sampled in this study had all necessarily survived the selected drought events. Trees which died during these drought events might have had an impact at the stand level on the stand composition effect. A long-term survey including mortality is needed to 537 more precisely define the effects of stand composition on individuals' response to drought. Lastly, the stand composition effect might be reflected in structural characteristics other than ring widths. There is a growing number of studies focusing on other wood characteristics such as the relative widths of earlywood and latewood, the number and size of vessels, and ring

541 density. These parameters would add a degree of precision to the understanding of the 
542 processes governing tree growth and cambial activity (Martinez-Vilalta and Pñol, 2002;

543 Eilmann et al., 2009; Martín-Benito et al., 2013; Vieira et al., 2014).

544

545

4.3. The tree size effect on individual tree response to drought varies between species

In Pinus sylvestris large trees were more sensitive than small trees to drought, while no clear trend was observed for Quercus petraea (Table 5, Table 6).

\subsubsection{Small oak response seems better for older droughts than for recent droughts}

The results obtained for sessile oak show varying effects of tree size depending on the drought event and the index (Table 5, Figure 4). We observed a better response of small trees for the 1990-1992 drought (resistance), and the oppposite for the 2003 (resistance), and 2010 droughts (recovery) while medium-sized trees responded better in terms of recovery for the 2006 drought. Several hypotheses could be made to explain these results. As it has been suggested before, the type of drought could play a major role in shaping trees' responses to such disturbances. The 1990-1992 drought and the 2003 drought have very different characteristics: the first one was a drought spanning several years and more related to water stress than temperature stress while the second one was very short and intense and more related to temperature stress. The 2003, 2006 and 2010 droughts were frequent, happening only a few years apart from each other while the 1990-1992 drought happened 15 years after the previous drought which was in 1976. Small and large trees could reasonably respond differently to these varying characteristics of droughts, explaining the results we observed in our study. Processes related to drought hardening for example in small trees as suggested by Martín-Benito et al. (2008) might confer them an advantage while large trees might recover faster in the favorable years following a drought (Martín-Benito et al., 2008; Martínez-Vilalta et al., 2012). Moreover, we could imagine that oaks could respond differently to droughts as 
they grow older (as suggested by Lloret et al. (2011) and Martínez-Vilalta et al. (2012) for pine species) leading to a potential change in the direction of the individual tree response to different drought effects, as we observed between the 1990-1992 drought and the following droughts. Unfortunately, very few references could be found and our results could not support one hypothesis more than another.

\subsubsection{Small pines' response to drought is better than large pines}

The results for Scots pine are unambiguous: when tree size is significant, trees of lower size (e. g. medium or small) have better responses to drought than large trees in terms of resistance, and above all, resilience (Table 6, Figure 5). It can be noted that these differences are observed only for summer droughts (no tree size effect for the 1990-1992 and 2010 spring droughts). In our stands, the variability of Scots pine diameters is associated with a stratification of tree crowns (through different crown transparency and expansion). Thus, microsite climatic conditions (humidity, temperature or solar radiation) might be kept relatively favorable for small trees, providing them with better growing conditions despite the overall drought conditions (Aussenac, 2000). Small trees may also be drought-hardened due to their position in the stand. Their need for carbon, nutrients and water would thus be reduced while their efficiency to use these resources might be enhanced. These droughthardening adaptations (Martín-Benito et al., 2008) as well as the micro-climatic conditions could enable the small trees to sustain growth while conditions are too harsh for large trees with high resource and maintenance needs as found in the literature (Martín-Benito et al., 2008; Martínez-Vilalta et al., 2012; Zang et al., 2012).

However, other results in the literature contradict our results, showing that small trees are more affected by drought events than large trees (Orwig and Abrams, 1997; Pichler and Oberhuber, 2007) due to a shallower root system or increased intraspecific competition 
590 (Martín-Benito et al., 2008; Zang et al., 2012), or no tree size effect at all (Mérian and 591 Lebourgeois, 2011).

592

Variability in the definition and magnitude of the tree size classes analyzed and the indices used in other studies and in ours may play a role in these conflicting results. Different soil and climatic conditions at each study site can also modify the response thresholds of individual trees. Finally, our study shows that in the same environmental context, the tree size effect varies according to the species considered (Lebourgeois et al., 2014), though we have yet to provide an explanation for this variation. Nevertheless, it is important to take into account the tree size classes within a stand in the study of the responses to climatic and/or biotic disturbances, as some previous studies have noted (Orwig and Abrams, 1997; Martín-Benito et al., 2008; MÉrian and Lebourgeois, 2011; Zang et al., 2012; Eilmann et al., 2013).

\section{Conclusion}

Our study confirms the differing responses of sessile oak and Scots pine to several specific drought events. Our results suggest that summer and spring droughts do not have the same impact on different species, though the limited number of drought events in our data did not enable us to test this hypothesis. The two species' contrasted growth dynamics and timing may lead to different consequences from a spring or a summer drought. Specific responses to different types of drought should be considered in future studies. Our results indicated no adverse or beneficial effects of mixture on the two species' resistance, resilience and recovery to drought. Tree size significantly affected both species, though the direction of this effect was not clear in sessile oak while it was for Scots pine, showing a better response of small trees to drought events. We hypothesize that intra-specific facilitation and/or physiological adaptations confer an advantage to small individuals during periods of water stress, though results from the literature are contradictory. The long-term monitoring of forest stands makes it possible to take into consideration mortality events following disturbances; a severe drought 
615

616

617

618

619

620

621

622

623

624

625

626

627

628

629

630

631

632

633

634

635

636

can speed up the mortality process for weak trees (Pedersen, 1998; Galiano et al., 2010) but

less so for strongly growing trees. Such experiments are in progress in the research unit where the OPTMix experimental site is located. Our study provides support for good resilience among surviving individuals of sessile oak and Scots pine in this lowland forest, which is facing climate change and increased drought frequency. This research is essential to adapt forest management strategies to changing conditions, while taking economic requirements into account.

\section{Acknowledgements}

This work was carried out at the OPTMix site, and funded by the Centre region. The authors also wish to thank the French National Forest Office for their support in collecting the data, and Vincent Seigner and Sébastien Macéfor the field work.

\section{References}

Allen, C.D., Macalady, A.K., Chenchouni, H., Bachelet, D., McDowell, N., Vennetier, M., Kitzberger, T., Rigling, A., Breshears, D.D., Hogg, E.H., Gonzalez, P., Fensham, R., Zhang, Z., Castro, J., Demidova, N., Lim, J.H., Allard, G., Running, S.W., Semerci, A., Cobb, N., 2010. A global overview of drought and heat-induced tree mortality reveals emerging climate change risks for forests. For. Ecol. Manage. 259, 660-684.

Aussenac, G., 2000. Interactions between forest stands and microclimate: Ecophysiological aspects and consequences for silviculture. Ann. Forest Sci. 57, 287-301.

Biéda, N., Badeau, V., 2008. Forest tree responses to extreme drought and some biotic events: Towards a selection according to hazard tolerance? Comptes Rendus Geoscience 340, 651662. 
Béda, N., Huc, R., Granier, A., Dreyer, E., 2006. Temperate forest trees and stands under severe drought: a review of ecophysiological responses, adaptation processes and longterm consequences. Ann. Forest Sci. 63, 625-644.

Bunn, A.G., Jansma, E., Korpela, M., Westfall, R.D., Baldwin, J., 2013. Using simulations and data to evaluate mean sensitivity (zeta) as a useful statistic in dendrochronology. Dendrochronologia 31, 250-254.

Cavin, L., Mountford, E.P., Peterken, G.F., Jump, A.S., 2013. Extreme drought alters competitive dominance within and between tree species in a mixed forest stand. Funct. Ecol. 27, 1424-1435.

Charru, M., Seynave, I., Morneau, F., Rivoire, M., Bontemps, J.D., 2012. Significant differences and curvilinearity in the self-thinning relationships of 11 temperate tree species assessed from forest inventory data. Ann. Forest Sci. 69, 195-205.

Chaves, M.M., Maroco, J.P., Pereira, J.S., 2003. Understanding plant responses to drought from genes to the whole plant. Funct. Plant Biol. 30, 239-264.

Cheaib, A., Badeau, V., Boe, J., Chuine, I., Delire, C., Dufiêne, E., Fraņ̧ois, C., Gritti, E.S., Legay, M., Pagé, C., Thuiller, W., Viovy, N., Leadley, P., 2012. Climate change impacts on tree ranges: model intercomparison facilitates understanding and quantification of uncertainty. Ecol. Lett. 15, 533-544.

Ciais, P., Reichstein, M., Viovy, N., Granier, A., Ogée, J., Allard, V., Aubinet, M., Buchmann, N., Bernhofer, C., Carrara, A., Chevallier, F., De Noblet, N., Friend, A.D., Friedlingstein, P., Günwald, T., Heinesch, B., Keronen, P., Knohl, A., Krinner, G., Loustau, D., Manca, G., Matteucci, G., Miglietta, F., Ourcival, J.M., Papale, D., Pilegaard, K., Rambal, S., Seufert, G., Soussana, J.F., Sanz, M.J., Schulze, E.D., Vesala, T., Valentini, R., 2005. Europe-wide reduction in primary productivity caused by the heat and drought in 2003 . Nature 437, 529-533. 
662 Cochard, H., Tyree, M.T., 1990. Xylem dysfunction in Quercus: vessel sizes, tyloses, cavitation and seasonal changes in embolism. Tree Physiol. 6, 393-407.

664

665

666

667

668

669

670

671

672

673

674

675

676

677

678

679

680

681

682

683

684
Corcuera, L., Camarero, J.J., Gil-Pelegnín, E., 2004. Effects of a severe drought on growth and wood anatomical properties of Quercus faginea. Iawa Journal 25, 185-204.

Dawson, T.E., 1996. Determining water use by trees and forests from isotopic, energy balance and transpiration analyses: The roles of tree size and hydraulic lift. Tree Physiol. 16, 263272.

Dhôte, J.F., 1994. Hypotheses about competition for light and water in even-aged common beech (Fagus sylvatica L.). For. Ecol. Manage. 69, 219-232.

Eilmann, B., Dobbertin, M., Rigling, A., 2013. Growth response of Scots pine with different crown transparency status to drought release. Ann. Forest Sci. 70, 685-693.

Eilmann, B., Weber, P., Rigling, A., Eckstein, D., 2006. Growth reactions of Pinus sylvestris L. and Quercus pubescens Willd. to drought years at a xeric site in Valais, Switzerland. Dendrochronologia 23, 121-132.

Eilmann, B., Zweifel, R., Buchmann, N., Fonti, P., Rigling, A., 2009. Drought-induced adaptation of the xylem in Scots pine and pubescent oak. Tree Physiol. 29, 1011-1020.

Eilmann, B., Zweifel, R., Buchmann, N., Pannatier, E.G., Rigling, A., 2011. Drought alters timing, quantity, and quality of wood formation in Scots pine. J. Exp. Bot. 62, 2763-2771.

Felton, A., Lindbladh, M., Brunet, J., Fritz,Ö, 2010. Replacing coniferous monocultures with mixed-species production stands: An assessment of the potential benefits for forest biodiversity in northern Europe. For. Ecol. Manage. 260, 939-947.

Forrester, D.I., Bauhus, J., Cowie, A.L., Vanclay, J.K., 2006. Mixed-species plantations of Eucalyptus with nitrogen-fixing trees: A review. For. Ecol. Manage. 233, 211-230. 
685

686

687

688

689

690

691

692

693

694

695

696

697

698

699

700

701

702

703

704

705

706

707

708

Galiano, L., Martínez-Vilalta, J., Lloret, F., 2010. Drought-Induced Multifactor Decline of Scots Pine in the Pyrenees and Potential Vegetation Change by the Expansion of Cooccurring Oak Species. Ecosystems 13, 978-991.

Galiano, L., Martínez-Vilalta, J., Lloret, F., 2011. Carbon reserves and canopy defoliation determine the recovery of Scots pine 4 yr after a drought episode. New Phytol. 190, 750759.

Grimm, V., Wissel, C., 1997. Babel, or the ecological stability discussions: An inventory and analysis of terminology and a guide for avoiding confusion. Oecologia 109, 323-334.

Grissino-Mayer, H.D., 2001. Evaluating Crossdating Accuracy: A Manual and Tutorial for the Computer Program COFECHA. Tree-Ring Research 57, 205-221.

Grossiord, C., Gessler, A., Granier, A., Pollastrini, M., Bussotti, F., Bonal, D., 2014. Interspecific competition influences the response of oak transpiration to increasing drought stress in a mixed Mediterranean forest. For. Ecol. Manage. 318, 54-61.

Gruber, A., Pirkebner, D., Florian, C., Oberhuber, W., 2012. No evidence for depletion of carbohydrate pools in Scots pine (Pinus sylvestris L.) under drought stress. Plant Biol. 14, $142-148$.

IPCC, 2013. : Summary for Policymakers. In, Climate Change 2013: The Physical Science Basis. Contribution of Working Group 1 to the Fifth Assessment Report of the Intergovernmental Panel on Climate Change. [Stocker, T. F., D. Qin, G.-K. Plattner, M. Tignor, S. K. Allen, J. Boschung, A. Nauels, Y. Xia, V. Bex and P. M. Midgley (eds.)]. Cambridge University Press, Cambridge, United Kingdom and New York, NY, USA.

IUSS Working Group, W.R.B., 2014. World Reference Base for Soil Resources 2014. In, World Soil Resources Reports. International soil classification system for naming soils and creating legends for soil maps. No. 106. FAO, Rome. 
Jactel, H., Brockerhoff, E.G., 2007. Tree diversity reduces herbivory by forest insects. Ecol. Lett. $10,835-848$.

Jucker, T., Bouriaud, O., Avacaritei, D., Dănilă, I., Duduman, G., Valladares, F., Coomes, D.A., 2014. Competition for light and water play contrasting roles in driving diversityproductivity relationships in Iberian forests. J. Ecol.

Kelty, M.J., 2006. The role of species mixtures in plantation forestry. For. Ecol. Manage. 233, 195-204.

Knoke, T., Ammer, C., Stimm, B., Mosandl, R., 2008. Admixing broadleaved to coniferous tree species: a review on yield, ecological stability and economics. Eur. J. Forest Res. 127, 89-101.

Korboulewsky, N., Balandier, P., Ballon, P., Boscardin, Y., Dauffy Richard, E., Dumas, Y., Ginisty, C., Gosselin, M., Hamard, J.P., Mace, S., Mårell, A., NDiaye, A., Perot, T., Perret, S., Rocquencourt, A., Seigner, V., Vallet, P., 2013. OPTMix - Oak Pine Tree Mixture Dispositif expérimental de long terme en fôêt mélangée. Atelier Regefor, la gestion de la fertilié de sols est-elle a un tournant ? In, Pème Colloque d'Ecologie des Communaúés Véǵtales, Tours, France.

Lebourgeois, F., Eberk, P., Mérian, P., Seynave, I., 2014. Social status-mediated tree-ring responses to climate of Abies alba and Fagus sylvatica shift in importance with increasing stand basal area. For. Ecol. Manage. 328, 209-218.

Lebourgeois, F., Gomez, N., Pinto, P., Mérian, P., 2013. Mixed stands reduce Abies alba treering sensitivity to summer drought in the Vosges mountains, western Europe. For. Ecol. Manage. 303, 61-71.

Lebourgeois, F., Rathgeber, C.B.K., Ulrich, E., 2010. Sensitivity of French temperate coniferous forests to climate variability and extreme events (Abies alba, Picea abies and Pinus sylvestris). J. Veg. Sci. 21, 364-376. 
Lloret, F., Escudero, A., Iriondo, J.M., Martínez-Vilalta, J., Valladares, F., 2012. Extreme climatic events and vegetation: the role of stabilizing processes. Global Change Biol. 18, 797-805.

Lloret, F., Keeling, E.G., Sala, A., 2011. Components of tree resilience: effects of successive low-growth episodes in old ponderosa pine forests. Oikos 120, 1909-1920.

Maestre, F.T., Callaway, R.M., Valladares, F., Lortie, C.J., 2009. Refining the stress-gradient hypothesis for competition and facilitation in plant communities. J. Ecol. 97, 199-205.

Martín-Benito, D., Beeckman, H., Cãellas, I., 2013. Influence of drought on tree rings and tracheid features of Pinus nigra and Pinus sylvestris in a mesic Mediterranean forest. Eur. J. Forest Res. 132, 33-45.

Martín-Benito, D., Cherubini, P., del Río, M., Cãellas, I., 2008. Growth response to climate and drought in Pinus nigra Arn. trees of different crown classes. Trees-Struct. Funct. 22, 363373.

Martínez-Vilalta, J., López, B.C., Loepfe, L., Lloret, F., 2012. Stand- and tree-level determinants of the drought response of Scots pine radial growth. Oecologia 168, 877-888.

Martinez-Vilalta, J., Pñol, J., 2002. Drought-induced mortality and hydraulic architecture in pine populations of the NE Iberian Peninsula. For. Ecol. Manage. 161, 247-256.

Mérian, P., Lebourgeois, F., 2011. Size-mediated climate-growth relationships in temperate forests: A multi-species analysis. For. Ecol. Manage. 261, 1382-1391.

Michelot, A., Biéda, N., Damesin, C., Dufiene, E., 2012a. Differing growth responses to climatic variations and soil water deficits of Fagus sylvatica, Quercus petraea and Pinus sylvestris in a temperate forest. For. Ecol. Manage. 265, 161-171.

Michelot, A., Simard, S., Rathgeber, C., Dufiêne, E., Damesin, C., 2012b. Comparing the intra-annual wood formation of three European species (Fagus sylvatica, Quercus petraea 
and Pinus sylvestris) as related to leaf phenology and non-structural carbohydrate dynamics. Tree Physiol. 32, 1033-1045.

Morán-López, T., Poyatos, R., Llorens, P., Sabaḱ, S., 2014. Effects of past growth trends and current water use strategies on Scots pine and pubescent oak drought sensitivity. Eur. J. Forest Res. 133, 369-382.

Niinemets, U., 2010. A review of light interception in plant stands from leaf to canopy in different plant functional types and in species with varying shade tolerance. Ecol. Res. 25, 693-714.

Niinemets, U., Valladares, F., 2006. Tolerance to shade, drought, and waterlogging of temperate Northern Hemisphere trees and shrubs. Ecol. Monogr. 76, 521-547.

Olivar, J., Bogino, S., Spiecker, H., Bravo, F., 2012. Climate impact on growth dynamic and intra-annual density fluctuations in Aleppo pine (Pinus halepensis) trees of different crown classes. Dendrochronologia 30, 35-47.

Orwig, D.A., Abrams, M.D., 1997. Variation in radial growth responses to drought among species, site, and canopy strata. Trees-Struct. Funct. 11, 474-484.

Palacio, S., Hoch, G., Sala, A., Kömer, C., Millard, P., 2014. Does carbon storage limit tree growth? New Phytol. 201, 1096-1100.

Pedersen, B.S., 1998. The role of stress in the mortality of midwestern oaks as indicated by growth prior to death. Ecology 79, 79-93.

Perot, T., Vallet, P., Archaux, F., 2013. Growth compensation in an oak-pine mixed forest following an outbreak of pine sawfly (Diprion pini). For. Ecol. Manage. 295, 155-161.

Pichler, P., Oberhuber, W., 2007. Radial growth response of coniferous forest trees in an inner Alpine environment to heat-wave in 2003. For. Ecol. Manage. 242, 688-699. 
Potop, V., Boroneant, C., Mož̌ý, M., Štěpánek, P., Skalakk, P., 2014. Observed spatiotemporal characteristics of drought on various time scales over the Czech Republic. Theor. Appl. Clim. 115, 563-581.

Pretzsch, H., Schiitze, G., Uhl, E., 2013. Resistance of European tree species to drought stress in mixed versus pure forests: evidence of stress release by inter-specific facilitation. Plant Biol. 15, 483-495.

R Development Core Team, 2014. R: A Language and Environment for Statistical Computing. In. R Foundation for Statistical Computing, Vienna, Austria.

Regent, I., 2005. Windendro 2005a. In. Universiédu Québec, Chicoutimi, Canada.

Reineke, L.H., 1933. Perfecting a stand-density index for even-aged forests. J. Agric. Res. 46, 627-638.

Smith, M.D., 2011. An ecological perspective on extreme climatic events: a synthetic definition and framework to guide future research. J. Ecol. 99, 656-663.

Speer, J.H., 2010. Fundamentals of Tree-Ring Research, Tucson, Arizona.

Taeger, S., Zang, C., Liesebach, M., Schneck, V., Menzel, A., 2013. Impact of climate and drought events on the growth of Scots pine (Pinus sylvestris L.) provenances. For. Ecol. Manage. 307, 30-42.

Tardif, J.C., Conciatori, F., 2006. Influence of climate on tree rings and vessel features in red oak and white oak growing near their northern distribution limit, southwestern Quebec, Canada. Canadian Journal of Forest Research-Revue Canadienne De Recherche Forestiere $36,2317-2330$.

Thornthwaite, C.W., 1948. An approach toward a rational classification of climate. Geogr. Rev. 38, 55-94.

Tyree, M.T., Cochard, H., 1996. Summer and winter embolism in oak: Impact on water relations. Ann. Forest Sci. 53, 173-180. 
806

807

808

809

810

Vacchiano, G., Garbarino, M., Mondino, E.B., Motta, R., 2012. Evidences of drought stress as a predisposing factor to Scots pine decline in Valle d'Aosta (Italy). Eur. J. Forest Res. $131,989-1000$.

Vallet, P., Perot, T., 2011. Silver fir stand productivity is enhanced when mixed with Norway spruce: evidence based on large-scale inventory data and a generic modelling approach. J. Veg. Sci. 22, 932-942.

van der Werf, G.W., Sass-Klaassen, U.G.W., Mohren, G.M.J., 2007. The impact of the 2003 summer drought on the intra-annual growth pattern of beech (Fagus sylvatica L.) and oak (Quercus robur L.) on a dry site in the Netherlands. Dendrochronologia 25, 103-112.

Vicente-Serrano, S.M., Begueńa, S., López-Moreno, J.I., 2010. A Multiscalar Drought Index Sensitive to Global Warming: The Standardized Precipitation Evapotranspiration Index. J. Clim. 23, 1696-1718.

Vieira, J., Rossi, S., Campelo, F., Freitas, H., Nabais, C., 2014. Xylogenesis of Pinus pinaster under a Mediterranean climate. Ann. Forest Sci. 71, 71-80.

Viĥ-Cabrera, A., Martínez-Vilalta, J., Galiano, L., Retana, J., 2013. Patterns of Forest Decline and Regeneration Across Scots Pine Populations. Ecosystems 16, 323-335.

Weber, P., Bugmann, H., Rigling, A., 2007. Radial growth responses to drought of Pinus sylvestris and Quercus pubescens in an inner-Alpine dry valley. J. Veg. Sci. 18, 777-792.

Wigley, T.M.L., Briffa, K.R., Jones, P.D., 1984. On the average value of correlated timeseries, with applications in dendroclimatology and hydrometeorology. J. Climate Appl. Meteorol. 23, 201-213.

Wiley, E., Huepenbecker, S., Casper, B.B., Helliker, B.R., 2013. The effects of defoliation on carbon allocation: can carbon limitation reduce growth in favour of storage? Tree Physiol. $33,1216-1228$. 
830 Zang, C., Pretzsch, H., Rothe, A., 2012. Size-dependent responses to summer drought in

831 Scots pine, Norway spruce and common oak. Trees-Struct. Funct. 26, 557-569.

832 Zweifel, R., Zimmermann, L., Zeugin, F., Newbery, D.M., 2006. Intra-annual radial growth

833 and water relations of trees: implications towards a growth mechanism. J. Exp. Bot. 57, $834 \quad 1445-1459$.

835

836 
837

Therefore, the error $R$ for each index based on BAI is:

$$
R_{n}=\frac{\left(d_{i, n-1}+R W_{i, n}\right)}{\left(d_{j, n-1}+R W_{j, n}\right)}
$$

848 This error was calculated on the Scots pine data for each drought event. The relative bias

\section{Appendices}

\section{A. Calculation of the relative bias in the index comparison between species}

In the following equations, $d_{i, n}$ is the mean diameter at drought event $n$ for the pre-drought, $R W_{i, n}$ or $B A I_{i, n}$ is respectively the ring width or tree basal area increment at drought event $n$.

The $i$ or $j$ subscript defines for which period - drought, pre-drought or post-drought - the variable is calculated depending on the relevant index.

The definition of BAI is as follows:

$$
B A I_{n}=\left(d_{n}^{2}-d_{n-1}^{2}\right) \times \frac{\pi}{4}
$$

which can be simplified as:

$$
B A I_{n}=\pi \times R W_{n} \times\left(d_{n-1}+R W_{n}\right)
$$

Therefore, we may write any index based on BAI as:

$$
\operatorname{Index}_{B A I, n}=\frac{B A I_{i, n}}{B A I_{j, n}}=\frac{\pi \times R W_{i, n} \times\left(d_{i, n-1}+R W_{i, n}\right)}{\pi \times R W_{j, n} \times\left(d_{j, n-1}+R W_{j, n}\right)}
$$

$$
\operatorname{Index}_{B A I, n}=\operatorname{Index}_{R W, n} \times \frac{\left(d_{i, n-1}+R W_{i, n}\right)}{\left(d_{j, n-1}+R W_{j, n}\right)}
$$

\footnotetext{
$1-R$ thus defined can be compared with the modeled difference between the species for each
} 
850 index. When the difference between species was significant, the relative bias was largely

851 under the modeled difference, as is shown in Figure A 1 for the resistance index.

852 Figure A 1. Relative bias in the comparison between oak RW and pine BAI. The modeled

853 difference in resistance to drought between oak and pine responses are plotted in dotted lines

854 for the drought events for which the species effect was significant. These dotted lines are far

855 beyond the mean relative bias, showing that the results we obtained are not confounded with

856 the error induced by using two different growth variables to calculate the indices.

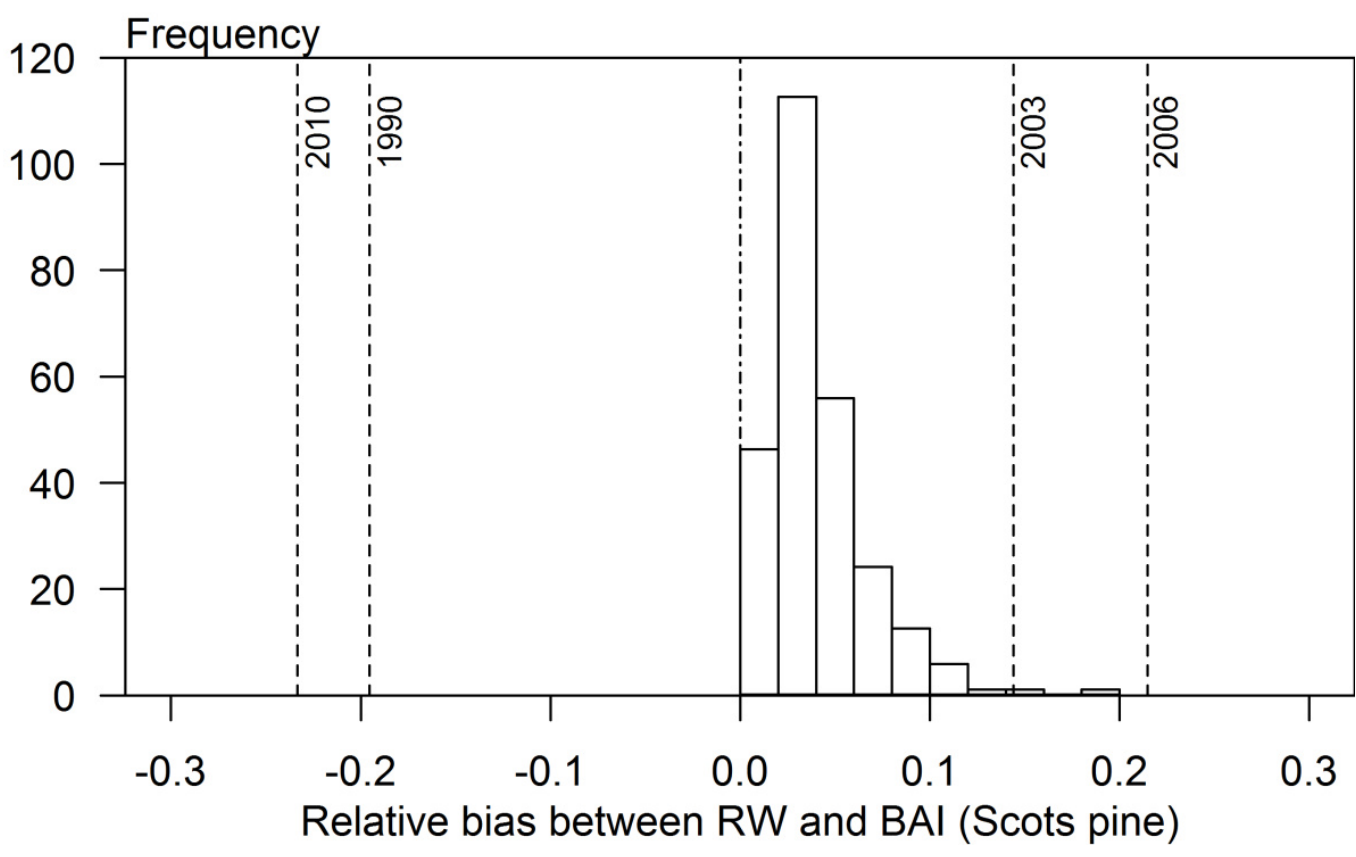




\section{B. COFECHA outputs for Scots pine and sessile oak tree-ring cross-validation}

Mean sensitivities values were discarded as it has been shown not to be a good estimator of the characteristics of a time-series (Bunn et al., 2013).

Table B 1. Selected COFECHA output for Scots pine individual tree series showing descriptive information on each individual (site, plot, subplot, first year and last year of the measured tree rings, cumulative number of years). The statistics calculated by COFECHA are shown in the following columns: correlation with master series (computed from the 54 individual series), the mean and maximum measurement (tree-ring widths) along with the standard deviation (s.d.) associated and the autocorrelation of each series.

$\begin{array}{rrrrrrr}\text { Site } & \text { Plot } & \text { Subplot } & \text { Individual } & \text { First year } & \text { Last year } & \text { Years } \\ 2 & \text { O200 } & 2 & 1 & 1952 & 2012 & 61 \\ 2 & \text { O200 } & 2 & 2 & 1950 & 2012 & 63 \\ 2 & \text { O200 } & 2 & 3 & 1955 & 2012 & 58 \\ 2 & \text { O200 } & 2 & 4 & 1957 & 2012 & 56 \\ 2 & \text { O200 } & 3 & 5 & 1952 & 2012 & 61 \\ 2 & \text { O200 } & 3 & 6 & 1951 & 2012 & 62 \\ 2 & \text { O200 } & 3 & 7 & 1950 & 2012 & 63 \\ 2 & \text { O200 } & 3 & 8 & 1950 & 2012 & 63 \\ 2 & \text { O200 } & 3 & 9 & 1951 & 2012 & 62 \\ 2 & \text { O216 } & 1 & 1 & 1955 & 2012 & 58 \\ 2 & \text { O216 } & 1 & 2 & 1958 & 2012 & 55 \\ 2 & \text { O216 } & 1 & 3 & 1952 & 2012 & 61 \\ 2 & \text { O216 } & 1 & 4 & 1957 & 2012 & 56 \\ 2 & \text { O216 } & 1 & 5 & 1960 & 2012 & 53 \\ 2 & \text { O216 } & 2 & 6 & 1959 & 2012 & 54 \\ 2 & \text { O216 } & 3 & 7 & 1959 & 2012 & 54\end{array}$

$\begin{array}{rrrrrr}\text { Correlation with Master Series } & \text { Mean } & \text { Max } & \text { s.d. } & \text { Autocorrelation } \\ 0.768 & 1.84 & 6.31 & 1.244 & 0.802 \\ 0.714 & 2.38 & 8.82 & 1.87 & 0.888 \\ 0.726 & 1.86 & 5.54 & 1.292 & 0.834 \\ 0.714 & 2.32 & 9.58 & 2.064 & 0.736 \\ 0.739 & 1.79 & 4.12 & 0.769 & 0.78 \\ 0.628 & 2.2 & 6.48 & 1.437 & 0.913 \\ 0.722 & 2.17 & 8.08 & 1.67 & 0.832 \\ 0.665 & 2.38 & 7.04 & 1.569 & 0.875 \\ 0.69 & 2.32 & 6.23 & 1.074 & 0.772 \\ 0.825 & 2.69 & 6.42 & 1.446 & 0.744 \\ 0.736 & 1.75 & 4.49 & 0.866 & 0.636 \\ 0.809 & 2.69 & 8.92 & 2.201 & 0.86 \\ 0.791 & 2.77 & 7.11 & 1.559 & 0.746 \\ 0.731 & 2.52 & 10.17 & 1.519 & 0.589 \\ 0.722 & 1.53 & 5.1 & 1.191 & 0.875 \\ 0.584 & 2.29 & 6.82 & 1.058 & 0.707\end{array}$




\begin{tabular}{|c|c|c|c|c|c|}
\hline 2 & $\mathrm{O} 216$ & 3 & 8 & 1963 & 2012 \\
\hline 2 & $\mathrm{O} 216$ & 3 & 9 & 1960 & 2012 \\
\hline 3 & O333 & 1 & 1 & 1961 & 2013 \\
\hline 3 & O333 & 1 & 2 & 1963 & 2013 \\
\hline 3 & O333 & 1 & 3 & 1962 & 2013 \\
\hline 3 & O333 & 1 & 4 & 1961 & 2013 \\
\hline 3 & O333 & 1 & 5 & 1964 & 2013 \\
\hline 3 & O333 & 2 & 6 & 1962 & 2013 \\
\hline 3 & O333 & 2 & 7 & 1960 & 2013 \\
\hline 3 & O333 & 2 & 8 & 1960 & 2013 \\
\hline 3 & O333 & 2 & 9 & 1959 & 2013 \\
\hline 3 & O333 & 2 & 1 & 1944 & 2012 \\
\hline 1 & O57 & 3 & 2 & 1948 & 2012 \\
\hline 1 & O57 & 3 & 3 & 1944 & 2012 \\
\hline 1 & O57 & 3 & 4 & 1943 & 2012 \\
\hline 1 & O57 & 3 & 5 & 1951 & 2012 \\
\hline 1 & O57 & 3 & 6 & 1943 & 2012 \\
\hline 1 & O57 & 4 & 7 & 1942 & 2012 \\
\hline 1 & O57 & 4 & 8 & 1941 & 2012 \\
\hline 1 & O57 & 4 & 9 & 1943 & 2012 \\
\hline 3 & O598 & 1 & 1 & 1940 & 2013 \\
\hline 3 & O598 & 1 & 2 & 1966 & 2013 \\
\hline 3 & O598 & 1 & 3 & 1963 & 2013 \\
\hline 3 & O598 & 1 & 4 & 1940 & 2013 \\
\hline 3 & O598 & 1 & 5 & 1958 & 2013 \\
\hline 3 & O598 & 2 & 6 & 1940 & 2013 \\
\hline 3 & O598 & 2 & 7 & 1952 & 2013 \\
\hline 3 & O598 & 3 & 8 & 1955 & 2013 \\
\hline 3 & O598 & 3 & 9 & 1938 & 2013 \\
\hline 1 & O83 & 2 & 1 & 1960 & 2012 \\
\hline
\end{tabular}

$\begin{array}{rrrrr}0.714 & 2.64 & 6.28 & 1.168 & 0.592 \\ 0.734 & 1.9 & 8.47 & 1.298 & 0.554 \\ 0.733 & 2.57 & 5.28 & 1.254 & 0.756 \\ 0.7 & 2.99 & 7.56 & 1.679 & 0.87 \\ 0.747 & 2.22 & 6.68 & 1.269 & 0.84 \\ 0.554 & 2.68 & 7.57 & 1.36 & 0.812 \\ 0.45 & 1.71 & 3.86 & 0.82 & 0.788 \\ 0.553 & 2.54 & 6.25 & 1.232 & 0.807 \\ 0.646 & 2 & 5.16 & 1.013 & 0.776 \\ 0.518 & 2.78 & 8.8 & 1.788 & 0.754 \\ 0.766 & 2.41 & 6.41 & 1.486 & 0.848 \\ 0.688 & 2.01 & 4.51 & 1.094 & 0.783 \\ 0.763 & 2.2 & 4.88 & 0.961 & 0.697 \\ 0.703 & 1.18 & 3.65 & 0.899 & 0.821 \\ 0.702 & 1.96 & 5.64 & 1.334 & 0.854 \\ 0.622 & 1.46 & 3.32 & 0.626 & 0.571 \\ 0.744 & 1.71 & 5.29 & 1.632 & 0.864 \\ 0.717 & 2.17 & 5.65 & 1.458 & 0.899 \\ 0.739 & 2.46 & 5.34 & 1.466 & 0.802 \\ 0.651 & 2.4 & 6.31 & 1.237 & 0.805 \\ 0.736 & 1.82 & 3.93 & 0.701 & 0.519 \\ 0.562 & 1.74 & 3.71 & 0.862 & 0.726 \\ 0.74 & 2.1 & 4.74 & 1.148 & 0.832 \\ 0.542 & 2.64 & 7.07 & 1.776 & 0.829 \\ 0.556 & 1.37 & 2.34 & 0.533 & 0.552 \\ 0.516 & 2.04 & 5.6 & 0.967 & 0.718 \\ 0.704 & 2.07 & 5.08 & 0.933 & 0.31 \\ 0.475 & 2.28 & 6.34 & 0.797 & 0.357 \\ 0.517 & 2.21 & 4.76 & 0.897 & 0.756 \\ 0.806 & 2.89 & 5.86 & 1.026 & 0.636\end{array}$


Author-produced version of the article published in Forest ecology and management, 2015, vol 339, p. 22-33, doi:10.1016/j.foreco.2014.11.032 The original publication is available at : http://www.sciencedirect.com/science/article/pii/S037811271400700

$\begin{array}{lllllll}1 & 083 & 2 & 2 & 1961 & 2012 & 52 \\ 1 & 083 & 2 & 3 & 1959 & 2012 & 54 \\ 1 & 083 & 2 & 4 & 1956 & 2012 & 57 \\ 1 & 0883 & 2 & 5 & 1960 & 2012 & 53 \\ 1 & 083 & 3 & 6 & 1959 & 2012 & 54 \\ 1 & 083 & 3 & 7 & 1960 & 2012 & 53 \\ 1 & 083 & 3 & 8 & 1961 & 2012 & 52 \\ 1 & 083 & 3 & 9 & 1959 & 2012 & 54\end{array}$

$\begin{array}{rrrr}0.592 & 2.15 & 4.86 & 0.889 \\ 0.546 & 2.58 & 5.39 & 0.855 \\ 0.638 & 2.55 & 9.65 & 2.007 \\ 0.701 & 1.87 & 4.55 & 0.936 \\ 0.459 & 2.22 & 5.35 & 1.209 \\ 0.432 & 3.41 & 7.2 & 1.254 \\ 0.71 & 3.41 & 6.31 & 0.906 \\ 0.465 & 2.71 & 7.57 & 1.464\end{array}$

0.685

0.714

0.855

0.69

0.846

0.737

0.468

0.866 
Table B 2. Selected COFECHA output for sessile oak individual tree series showing descriptive information on each individual (site, plot,

subplot, first year and last year of the measured tree rings, cumulative number of years). The statistics calculated by COFECHA are shown in the following columns: correlation with master series (computed from the 54 individual series), the mean and maximum measurement (tree-ring widths) along with the standard deviation (s.d.) associated and the autocorrelation of each series.

Site Plot Subplot Individual First year Last year Years

\section{$1 \mathrm{O} 12$}

$1 \mathrm{O} 12$

1012

1012

1012

1012

$\begin{array}{ll}1 & \mathrm{O} 12\end{array}$

1012

1012

20214

20214

20214

20214

$2 \mathrm{O} 214$

20214

20214

20214

$2 \mathrm{O} 214$

$2 \mathrm{O} 216$

20216

20216

$1944 \quad 2012 \quad 69$

$1942 \quad 2012 \quad 71$

$1944 \quad 2012 \quad 69$

$1941 \quad 2012 \quad 72$

$1941 \quad 2012 \quad 72$

$1942 \quad 2012 \quad 71$

$1943 \quad 2012 \quad 70$

$1943 \quad 2012 \quad 70$

$1946 \quad 2012 \quad 67$

$1948 \quad 2012 \quad 65$

$1954 \quad 2012 \quad 59$

$1951 \quad 2012 \quad 62$

$1955 \quad 2012 \quad 58$

$1947 \quad 2012 \quad 66$

$1950 \quad 2012 \quad 63$

$1950 \quad 2012 \quad 63$

$1953 \quad 2012 \quad 60$

$1951 \quad 2012 \quad 62$

$1957-2012 \quad 56$

$1956 \quad 2012 \quad 57$

$1958 \quad 2012 \quad 55$

Correlation with Master Series Mean Max s.d. Autocorrelation

$\begin{array}{rrrrr}0.805 & 1.31 & 3.16 & 0.577 & 0.367 \\ 0.576 & 1.38 & 2.54 & 0.481 & 0.455 \\ 0.682 & 1.34 & 2.73 & 0.411 & 0.249 \\ 0.595 & 0.94 & 3.14 & 0.466 & 0.683 \\ 0.667 & 1.63 & 2.94 & 0.488 & 0.543 \\ 0.661 & 1.11 & 2.76 & 0.412 & 0.552 \\ 0.652 & 0.78 & 3.96 & 0.615 & 0.764 \\ 0.571 & 0.74 & 3.04 & 0.47 & 0.704 \\ 0.688 & 1.59 & 3.72 & 0.649 & 0.559 \\ 0.509 & 1.32 & 3.73 & 0.616 & 0.363 \\ 0.612 & 1.32 & 3.38 & 0.461 & 0.447 \\ 0.541 & 0.75 & 2.24 & 0.372 & 0.422 \\ 0.5 & 0.91 & 3.41 & 0.569 & 0.686 \\ 0.769 & 1.43 & 3.78 & 0.604 & 0.462 \\ 0.812 & 1.24 & 3.2 & 0.471 & 0.405 \\ 0.767 & 1.76 & 3.88 & 0.737 & 0.609 \\ 0.713 & 1.74 & 3.65 & 0.67 & 0.602 \\ 0.628 & 0.93 & 2.47 & 0.494 & 0.479 \\ 0.718 & 1.05 & 1.79 & 0.368 & 0.506 \\ 0.75 & 1.31 & 2.93 & 0.456 & 0.513 \\ 0.433 & 0.91 & 3.83 & 0.671 & 0.612\end{array}$

$\begin{array}{llllll}0.433 & 0.91 & 3.83 & 0.671 & 0.612\end{array}$ 


$\begin{array}{lllllll}2 & 0216 & 1 & 4 & 1952 & 2012 & 61 \\ 2 & 0216 & 1 & 5 & 1954 & 2012 & 59 \\ 2 & 0216 & 1 & 6 & 1958 & 2012 & 55 \\ 2 & 0216 & 2 & 7 & 1953 & 2012 & 60 \\ 2 & 0216 & 2 & 8 & 1950 & 2012 & 63 \\ 2 & 0216 & 2 & 9 & 1953 & 2012 & 60 \\ 1 & 057 & 1 & 1 & 1938 & 2012 & 75 \\ 1 & 057 & 2 & 2 & 1937 & 2012 & 76 \\ 1 & 057 & 3 & 3 & 1944 & 2012 & 69 \\ 1 & 057 & 3 & 4 & 1943 & 2012 & 70 \\ 1 & 057 & 4 & 5 & 1940 & 2012 & 73 \\ 1 & 057 & 4 & 6 & 1952 & 2012 & 61 \\ 1 & 057 & 4 & 7 & 1937 & 2012 & 76 \\ 1 & 057 & 4 & 8 & 1935 & 2012 & 78 \\ 1 & 057 & 4 & 9 & 1937 & 2012 & 76 \\ 3 & 0593 & 2 & 1 & 1971 & 2013 & 43 \\ 3 & 0593 & 2 & 2 & 1950 & 2013 & 64 \\ 3 & 0593 & 2 & 3 & 1951 & 2013 & 63 \\ 3 & 0593 & 2 & 4 & 1948 & 2013 & 66 \\ 3 & 0593 & 2 & 5 & 1950 & 2013 & 64 \\ 3 & 0593 & 2 & 6 & 1948 & 2013 & 66 \\ 3 & 0593 & 3 & 7 & 1950 & 2013 & 64 \\ 3 & 0593 & 3 & 8 & 1950 & 2013 & 64 \\ 3 & 0593 & 3 & 9 & 1947 & 2013 & 67 \\ 3 & 0598 & 1 & 1 & 1933 & 2013 & 81 \\ 3 & 0598 & 1 & 2 & 1944 & 2013 & 70 \\ 3 & 0598 & 2 & 3 & 1942 & 2013 & 72 \\ 3 & 0598 & 2 & 4 & 1934 & 2013 & 80 \\ 3 & 0598 & 2 & 1937 & 2013 & 77 \\ 3 & 0598 & 2 & 1950 & 2013 & 64\end{array}$

$\begin{array}{rrrrr}0.687 & 1.69 & 3.06 & 0.616 & 0.574 \\ 0.724 & 1.75 & 2.86 & 0.607 & 0.583 \\ 0.651 & 1.09 & 2.48 & 0.398 & 0.354 \\ 0.608 & 1.38 & 3.35 & 0.64 & 0.653 \\ 0.722 & 1.82 & 3.66 & 0.734 & 0.774 \\ 0.708 & 1.2 & 2.61 & 0.517 & 0.62 \\ 0.658 & 1.29 & 3.02 & 0.517 & 0.622 \\ 0.46 & 1.04 & 2.69 & 0.507 & 0.724 \\ 0.645 & 1.07 & 2.21 & 0.599 & 0.803 \\ 0.584 & 0.95 & 2.1 & 0.514 & 0.626 \\ 0.561 & 0.72 & 1.95 & 0.396 & 0.785 \\ 0.718 & 1.49 & 3.85 & 0.749 & 0.517 \\ 0.748 & 1.76 & 4.19 & 0.926 & 0.698 \\ 0.75 & 1.67 & 2.99 & 0.694 & 0.763 \\ 0.659 & 1.33 & 4.61 & 0.64 & 0.637 \\ 0.866 & 1.57 & 3.13 & 0.441 & 0.352 \\ 0.843 & 1.92 & 4.59 & 0.679 & 0.406 \\ 0.556 & 1.4 & 3.09 & 0.601 & 0.597 \\ 0.513 & 0.96 & 3.4 & 0.608 & 0.632 \\ 0.596 & 1.64 & 3.14 & 0.543 & 0.577 \\ 0.735 & 1.92 & 3.7 & 0.813 & 0.694 \\ 0.752 & 1.76 & 4.26 & 0.673 & 0.516 \\ 0.675 & 0.93 & 3.28 & 0.455 & 0.546 \\ 0.708 & 1.45 & 3.46 & 0.54 & 0.54 \\ 0.655 & 1.4 & 5.96 & 0.748 & 0.623 \\ 0.235 & 0.73 & 1.74 & 0.412 & 0.628 \\ 0.581 & 1.47 & 4.12 & 0.777 & 0.738 \\ 0.301 & 1.26 & 2.08 & 0.328 & 0.491 \\ 0.521 & 1.27 & 3.08 & 0.694 & 0.72 \\ 0.37 & 0.73 & 1.64 & 0.422 & 0.634\end{array}$


Author-produced version of the article published in Forest ecology and management, 2015, vol 339, p. 22-33, doi:10.1016/j.foreco.2014.11.032 The original publication is available at : http://www.sciencedirect.com/science/article/pii/S037811271400700

$\begin{array}{lllllll}3 & 0598 & 3 & 7 & 1940 & 2013 & 74 \\ 3 & 0598 & 3 & 8 & 1940 & 2013 & 74 \\ 3 & 0598 & 3 & 9 & 1934 & 2013 & 80\end{array}$

$\begin{array}{rrrr}0.184 & 0.84 & 2.89 & 0.646 \\ 0.646 & 1.66 & 3.27 & 0.642 \\ 0.59 & 1.95 & 3.87 & 0.687\end{array}$

0.872

0.614 